Research Division

Federal Reserve Bank of St. Louis

Working Paper Series

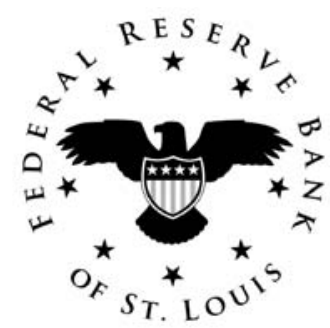

\title{
African-American Economic Progress in Urban Areas: A Tale of 14 American Cities
}

\author{
Dan A. Black \\ Natalia Kolesnikova \\ and \\ Lowell J. Taylor
}

Working Paper 2010-015A

http://research.stlouisfed.org/wp/2010/2010-015.pdf

June 2010

FEDERAL RESERVE BANK OF ST. LOUIS

Research Division

P.O. Box 442

St. Louis, MO 63166

The views expressed are those of the individual authors and do not necessarily reflect official positions of the Federal Reserve Bank of St. Louis, the Federal Reserve System, or the Board of Governors.

Federal Reserve Bank of St. Louis Working Papers are preliminary materials circulated to stimulate discussion and critical comment. References in publications to Federal Reserve Bank of St. Louis Working Papers (other than an acknowledgment that the writer has had access to unpublished material) should be cleared with the author or authors. 


\title{
African-American Economic Progress in Urban Areas:
}

\section{A Tale of 14 American Cities}

\author{
Dan A. Black, Natalia Kolesnikova, and Lowell J. Taylor
}

ABSTRACT. How significant was the economic progress of AfricanAmericans in the U.S. between 1970 and 2000? In this paper we examine this issue for black men 25-55 years old who live in 14 large U.S. metropolitan areas. We present the evidence that significant racial disparities remain in education and labor market outcomes of black and white men. We discuss changes in industrial composition, migration, and demographic changes that might have contributed to the stagnation of economic progress of black men between 1970 and 2000. In addition, we show that there was no progress in a financial well-being of black children, relative to white children, between 1970 and 2000.

JEL: J15, J31, J71, R23.

Keywords: black economic progress, black-white economic convergence, inequality.

\section{Introduction}

How significant was the economic progress of African-Americans in the U.S. between 1970 and 2000? The common perception is that inequality between races has decreased. In 1954, the Supreme Court's decision in the famous Brown v. Board of Education case proclaimed racial segregation of public schools unconstitutional. It eventually paved way to the Civil Rights Act of 1964 that outlawed racial segregation in schools and at the workplace, among other provisions. The Act opened doors to better education, including higher education, for black children. Making racial discrimination illegal, the new law also offered greater opportunities to African-Americans in the labor markets. Did these societal changes translate into economic changes for blacks as 
well? Did earnings of blacks increased relative to earnings of whites? Did labor force attachment of blacks become more secure? How much did an educational attainment and skill acquisition improve? Did economic well-being of African-American children improve?

Most of the previous research on these topics was done on a national level. ${ }^{1}$ Such studies, at most, "control for" a region of living (such as South, Northeast, Midwest, etc) and/or urban status of the residence. This paper examines and compares various aspects of African-American progress in labor markets between 1970 and 2000 across large U.S. cities. There are several reasons for performing such analysis on a city-level, rather than on a national level. First, cities in the U.S. vary widely in their characteristics, including labor market conditions and industrial structure. Second, and more importantly, the history of black population is very different in different regions of the country. This warrants looking at Memphis and Detroit, for instance, separately to better analyze changes in economic conditions of blacks.

Finally, a recent study by Black et al. (2009) demonstrates that it is important to take into consideration geographic location when studying racial differences. Performing analysis on a national level masks underlying trends in local labor markets. ${ }^{2}$ The study shows, in particular, that a failure to account for city-specific differences in black-white wage gaps results in a significant (about 50 percent) overestimation of black-white wage gap conversion. In many local labor markets, especially high-productivity, high-wage markets, the black-white wage gap essentially stayed the same over the years. But as more and more black men moved into highwage cities, a national black-white wage gap has reduced dramatically even though there was

\footnotetext{
${ }^{1}$ A very good overview of existing studies is presented in Altonji and Blank (1999).

${ }^{2}$ Black et al (2009) also show that in a presence of location-specific wages and prices, a racial wage gap is the same across location only in a case of very specific (and usually not realistic) preferences.
} 
little change in each particular market. The reason for the seeming black-white wage convergence was not only a change in labor markets but simply a redistribution of black population from low-wage into high-wage markets, something that would not be apparent if looking only at the national averages.

It seems reasonable, therefore, to document economic progress of African-Americans in a context of a specific labor market and then compare it across cities. Performing such analysis is the goal of this paper. ${ }^{3}$

\section{Data Description}

In particular, we study an African-American progress in 14 cities from 1970 to 2000 . To be more precise, a unit of analysis is a Metropolitan Statistical Area (MSA) as defined by the Census Bureau. ${ }^{4}$ In what follows, we use words MSA and city interchangeably. We use the data from the 1970 through 2000 U.S. Censuses, provided by IPUMS. ${ }^{5}$ The 14 cities in the sample were chosen based on a criteria that an MSA had at least 700 black respondents in 1970 IPUMS Census data. They are Atlanta, Baltimore, Chicago, Cleveland, Detroit, Houston, Los Angeles,

\footnotetext{
${ }^{3}$ In this paper we concentrate on documenting city-specific changes in various measures of economic and social conditions of African-Americans leaving the explanation of the observed changes and differences in the observed changes to our future research.

${ }^{4}$ The general concept of a metropolitan statistical area (MSA) is that of a central city, together with adjacent communities having a high degree of economic and social integration with the central city.

${ }^{5}$ See Ruggles et al (2009).
} 
Memphis, New Orleans, New York, Philadelphia, St. Louis, San Francisco, and Washington metropolitan areas. ${ }^{6,7}$

In this paper we restrict the analysis to black and non-Hispanic white men, aged 25 to 55 years old. ${ }^{8}$ For each respondent in the sample, the data provide a wealth of information, including age, education attainment, employment status, income, industry and occupation of employment, class of worker, and marital status. ${ }^{9}$

An important concern with the Census data is that respondents occasionally choose not to answer some questions. The respondents who did not answer questions related to the issues of the study were not included in the sample. Also, the respondents who lived in institutions (such as correctional institutions) and non-institutional group quarters (such as military) were not included. Thus, the final sample consists of black and white men of an active working age, who are not in the military and not incarcerated. Increasing rates of incarceration of black men is an alarming trend and a subject of many studies. ${ }^{10}$ It is not a focus of this paper, however.

\footnotetext{
${ }^{6}$ There are no MSA identifiers in the 1960 data which makes it impossible to extend this analysis to earlier years. The smallest geographic unit in the 1960 data is a state.

${ }^{7}$ In 1970 a quite large proportion, about 43 percent, of black men of prime working age, 25 to 55 years old, lived in these 14 metropolitan areas. Nevertheless, it is worth pointing out that the results of the paper should not be taken as a picture of the economic progress of black men in the U.S. as a whole. Rather, the paper focuses on economic progress of black men in large urban area.

${ }^{8}$ A similar investigation of the economic progress of black women is equally interesting but presents additional challenges. There has been a significant change in labor force participation of black and white women over the studied period of time. In addition, women's attachment to the labor force tends to be weaker than men's because women often exit the labor force for childbearing and child care. This makes a direct comparison of white and black women's labor market outcomes even more complicated. It is an important topic that we plan to pursue in a future research.

${ }^{9}$ A detailed description of variables is provided in Appendix 1: Data and Variables Description.

${ }^{10}$ See, for example Western (2006) and Charles and Luoh (forthcoming). Charles and Luoh document an astonishing increase of incarceration rates of black men aged 20-35 between 1970 and 2000. For example, almost 30 percent of black men aged 20-35 were incarcerated in New Mexico in 2000, 23 percent in Wisconsin and
} 


\section{Changes in Relative Wages and Annual Earnings}

Many studies concentrate on wages as a measure of earnings. It is a logical approach because a wage is a price that labor markets put on a unit of labor of a certain skill level. In this case, decrease in the black-white wage gap means labor markets' valuations of black and white labor converge. It also indicates the convergence of skill levels of black and white workers.

However, difference in wages is only one of labor market characteristics that can potentially contribute to a racial economic disparity. There are other important factors such as labor force participation, unemployment, and underemployment. To better assess an economic progress of blacks, we consider a different measure-annual earnings, that take into consideration both wages and labor force attachment. Analyzing annual earnings instead of wages allows a better assessment of an overall economic well-being of an individual.

Table 1, adapted from Black et al. (2009), shows that there has been an increase in relative weekly wages of black men between 1970 and 2000 in all but three cities (Philadelphia, Chicago, and Detroit). The numbers represent a ratio of average weekly wages of black and white men, in a percent form. For example, in 1970 in Houston black men on average were earning 65 percent of weekly wages of white men. The ratio has increased to 72 percent in 2000. Atlanta experienced the largest increase in relative wages of black men. In 1970 black men in Atlanta were making about 62 percent of white men’s weekly wages. By 2000 the ratio has increased by 16 percentage points, to 78 percent. Philadelphia, Chicago, and Detroit had relative wages of black men decrease between 1970 and 2000 but only slightly: from 79 to 77 percent in Philadelphia, from 75 to 74 percent in Chicago, and from 81 to 78 percent in Detroit.

Minnesota, 22 percent in Arizona. The lowest incarceration rate in 2000 was 7 percent, in the District of Columbia. For comparison, states incarceration rates of white men in 2000 ranged between 0.8 and 3.2 percent. 


\section{$<$ Table 1 $>$}

Table 2 provides a summary of changes of black-white annual earnings ratios in 14 cities from 1970 to $2000 .^{11}$ The picture of economic progress of black men is much less bright when we consider their annual earnings. In contrast to weekly wages, relative annual earnings have declined in most cities. In southern cities, that did experience an increase in relative annual earnings of black men, most of the progress happened between 1970 and 1980 with no significant changes after that. In Chicago, where relative annual earnings fell the most (14 percentage points), black men were earning 69 percent of white men’s annual income in 1970 but only 55 percent by 2000. Most of Midwestern and Eastern cities in the sample have experienced a similar decline. Interestingly, the magnitude and timing of the decrease in relative annual earnings of black man vary across cities. In New York, for example, the overall decrease of 10 percentage points was spread somewhat equally over these three decades. In Philadelphia almost a 10 percentage point drop between 1970 and 1980 was followed by virtually no change after 1980. In Cleveland the largest decrease occurred between 1980 and 1990. In Detroit and St. Louis two decades of regress were followed by a 3 percentage point increase in relative annual earnings of black men between 1990 and 2000. In Baltimore and Los Angeles, in contrast, the black-white annual earnings ratio remained pretty stable over the three decades.

\section{$<$ Table 2>}

\section{Changes in Labor Force Participation}

The main reason for the discrepancy between the two measures of economic progress of black men in 1970-2000 is a labor force attachment of black men. There has been a significant

\footnotetext{
${ }^{11}$ See Appendix 2 for details of estimation.
} 
decline in average number of weeks that black men work per year between 1970 and 2000. This, of course, affects their average annual earnings. Figure 1 illustrates this fact and Table 3 reports corresponding numbers. ${ }^{12}$ The average number of week of work per year decreased in every city; in some of them by as much as 25 percent. In 2000 black men on average worked only 33 weeks a year in San Francisco (down from 42 weeks in 1970), 34 weeks in Los Angeles and Chicago (down from 43 and 45 weeks in 1970), and 35 weeks in Detroit (down from 45 weeks in 1970). Atlanta and Washington are the cities with the highest average number of weeks worked in 2000, 41 weeks. But even this number is not higher than average number of weeks worked by black men in any of the 14 cities in $1970 .^{13}$

\section{$<$ Table 3>}

\section{$<$ Figure 1 $>$}

Figure 2 and Table 4 demonstrate that, in contrast, the weekly hours of work stayed remarkably stable between 1970 and 2000 with relatively small increases in some cities and decreases in others. ${ }^{14,15}$

\section{$<$ Table 4>}

\section{$<$ Figure 2>}

\footnotetext{
${ }^{12}$ See Appendix 2 for details of the estimation. It describes, in particular, an imputation technique for 1970 data.

${ }^{13}$ In comparison, white men have experienced only a small decline in their average weeks of work: from 47-49 weeks in 1970 to 43-48 weeks in 2000. The largest decline, from 47 weeks in 19070 to 43 weeks in 2000, occurred in New York and Los Angeles. In the rest of the cities white men worked on average 1-2 weeks less a year in 1970 than in 2000. Detailed results are available from the authors upon request.

${ }^{14}$ See Appendix 2 for details of the estimation. It describes, in particular, an imputation technique for 1970 data.

${ }^{15}$ Weekly hours of white men increased slightly over the same period in all 14 cities: from $39-43$ hours a week in 1970 to 40-45 hours a week in 2000. Detailed results are available from the authors upon request.
} 
A low number of weeks that black men worked on average in 2000 not only implies underemployment for many of them but also that many black men do not work at all, which drives the average numbers down.

To better assess changes in labor force participation of black men between 1970 and 2000, Table 5 reports proportion of black men who had a job, were unemployed, or were out of the labor force. The table shows two main changes over the period between 1970 and 2000: decrease in proportion of black men who have a job and increase in proportion of black men who report themselves as being out of the labor force. The table also demonstrates that in a number of cities there was a rise of unemployment rate in 1980 and 1990 followed in 2000 by a decrease of unemployment rate together with an increase of proportion of black men who were out of the labor force. The observed trend seems to be consistent with a "discouraged workers" explanation: when unemployment rate is high for a prolonged period of time, workers who are looking for jobs give up and opt out of the labor force and thus are not counted as unemployed. ${ }^{16}$ Consider Chicago, for example. In 1970, 88 percent of black men there had jobs, the unemployment rate was 4 percent, and 8 percent of black men were not in the labor force. By 1980, the number of employed black men dropped to 75 percent with 10 percent unemployment rate and 14 percent of black men were out of the labor force. Things kept getting worse, and by 1990, 71 percent were employed, 13 percent were unemployed, and 16 percent were not in the labor force. In 2000, the rate of employment for black men decreased further, to 69 percent. Unemployment rate has actually decreased from 13 percent to 9 percent. The proportion of black

\footnotetext{
${ }^{16}$ There is evidence that an access to the personal job search networks is very important. Holzer (1987) finds that "informal methods of job search account for 87-90 percent of the difference in youth employment probabilities between blacks and whites." Calvo-Armengol and Jackson (2004) use a similar social network approach to argue that probability of obtaining a job decreases with the length of time one remains unemployed. They also examine related inequality. In particular, they show that "if one group starts with worse employment status, then that group's drop-out rate will be higher and their employment prospects will be persistently below that of the other group."
} 
men who were out of labor force, however, went to a staggering 22 percent. ${ }^{17} \mathrm{~A}$ similar pattern of changes in the labor force can be observed in many other cities, including Houston, New Orleans, St. Louis, Cleveland, Detroit, and Philadelphia. In 2000 in 10 out of 14 cities the proportion of out of the labor force black men was above 20 percent. This high level of black men opting out of the labor force is observed even in cities where unemployment rate was relatively stable at 7-9 percent, such as Los Angeles and San Francisco.

\section{$<$ Table 5 $>$}

All cities, except Atlanta, have experienced a decrease in employment rates of black men between 1970 and 2000 by 11-19 percentage points. Atlanta had much smaller drop of only 6 percentage points as the proportion of black men who had a job has declined from 87 percent to 81 percent. In 2000 Atlanta had highest employment rate of black men and lowest unemployment rate. We will discuss in more details below what sets Atlanta apart.

To sum up, between 1970 and 2000 in 14 major urban areas in the U.S. black men has experienced significant decrease in their rates of employment while unemployment and rates of opting out of the labor force have increased. As a result, their average number of annual weeks of work and relative to white men annual earnings have decreased dramatically.

Why did this happen? What were the contributing factors? To begin answering these important questions we need to take a closer look at changes in the labor markets and in social structures.

\footnotetext{
17 To put the numbers in the right context, it is worth reminding that the sample consists of prime age (25-55 years old) black men who are not incarcerated and are not in the military.
} 


\section{Changes in Educational Attainment.}

A big part of black-white economic convergence is attributed to a significant increase in educational attainment levels of blacks over the last century. We consider five major educational categories: less than high school; high school diploma or GED; some college but no bachelor's degree; bachelor's degree; above bachelor's degree. Table 6 reports proportion of black men in each educational category for each of the 14 cities. For comparison, Table 7 provides similar statistics for white men.

\section{$<$ Tables 6 and 7>}

There are several main points worth noting. First, in 1970 majority of black men had less than a high school education in most cities. The situation was the worst in the South. In Memphis 77 percent of black men who were 25 to 55 years old in 1970 had less than a completed high school education. Only 7 percent had some college experience and only 3 percent received a bachelor's degree or higher. In New Orleans 70 percent of black man in 1970 did not have a high school education. The situation was much better in the West, where only 38 and 42 percent did not have a high school diploma in Los Angeles and San Francisco, respectively. Washington also had relatively small proportion of black men without a high school diploma in 1970, 47 percent.

Second, there has been a significant progress in educational attainment of black men between 1970 and 2000. In 2000 only 26 percent (down from 70 percent in 1970) of black men aged 25 to 55 living in New Orleans did not have a high school diploma. This proportion is even smaller in other 13 cities. The fraction of blacks who went to college significantly increased as well, although less than a half of those who pursued their education beyond high school received a bachelor's degree or higher. 
Third, despite the progress made by black men in terms of improving educational attainment, they still lag far behind white men. Figure 3 illustrates this point. The first graph shows a fraction of men in each of the 14 cities who did not have a high school education in 1970 and in 2000. Dark bars represent black men, light bars represent white men. The second graph shows similar fractions of men with exactly a high school diploma (or a GED) while the third graph presents the results for men with at least a bachelor's degree.

Figure 3 makes it easy to see that the proportion of black men without a high school diploma dropped considerably in all cities between 1970 and 2000. The progress was more significant in Southern cities than in Midwestern and Eastern cities. However, in all cities but Atlanta the rates of black men not completing a high school are still at least twice as big as those of white men. In 2000 in all cities, except New Orleans, less than 10 percent of white men did not complete a high school. In contrast, in 9 out of 14 cities at least 19 percent of black men did not have a high school diploma.

\section{$<$ Figure 3 $>$}

Given a sharp rise in the demand for educated labor over the last several decades, it is particularly alarming that very small number of black men had a bachelor's degree or a higher degree even by a year 2000. Washington and Atlanta had the largest proportions of black men with at least a bachelor's degree in 2000: 26 and 23 percent, respectively. However, almost twice as many, 58 and 44 percent, respectively, white men in these cities had at least a bachelors' degree. In cities such as Memphis, New Orleans, St. Louis, Cleveland, and Detroit only 12-14 percent of black men have graduated from college. In San Francisco, where 62 percent of white men in 2000 had at least a bachelor's degree, only 23 percent of black men did. 
Tables 6 and 7 and Figure 3 demonstrate that despite a important gains in educational attainment that black men had between 1970 and 2000, they still do not have levels of education anywhere similar to those of white men. There is an additional concern with a quality of education that black men receive, especially in inner city schools in major urban areas. Progress in educational attainment in itself is not as important as a resulting black-white convergence in skill levels. It has been shown that black-white skill convergence stopped since the late 1980 s. $^{18}$

\section{De-Industrialization and Changes in Industrial Composition}

Industrial composition has changed considerably in 1970-2000, especially in manufacturing cities. De-industrialization hurt both blacks and whites but blacks were more affected. One of the reasons is that, as we discuss below, black men were more likely to be employed in manufacturing industries. Another is that black men on average have lower level of educational attainment which makes it harder for them to adapt to new labor market conditions and to find new jobs in a different industry. Also, as more and more jobs require training beyond high school, black men are in a worse position than white men because of their relatively low education levels. ${ }^{19}$

Table 8 provides information about changes in distribution of all working men across industries between 1970 and 2000. Table 9 reports similar statistics for black men only. The main story of the three decades between 1970 and 2000 is a decline in manufacturing employment and a rise in a number of people working in service industry. Proportion of men

\footnotetext{
${ }^{18}$ See Neal (2006) for an excellent discussion of the topic.

${ }^{19}$ Bound and Holzer (1993) show that decline in manufacturing in the 1970s and 1980s reduced employment for both blacks and whites. They also find that blacks generally had larger employment declines than whites. Other studies (Bound and Freeman (1992), for example) show similar results. Bound and Johnson (1992) find that during the 1980s the labor demand has shifted dramatically towards high-skilled labor which was a major cause of a huge increase in relative wages of highly educated workers.
} 
employed in other industries changed very little. With the exception of Washington, where government jobs historically dominated, employment of men in manufacturing dropped by at least 8 percentage points (as in New Orleans). In cities that were predominantly industrial, such as St. Louis, Cleveland, Chicago, Detroit, Baltimore, manufacturing employment fell by 17-19 percentage points. In Detroit, for instance, 51 percent of men in 1970 were working in manufacturing. That number declined to 33 percent by 2000. Cleveland has experienced similar decrease in manufacturing employment: from 45 percent in 1970 to 26 percent in 2000.

\section{$<$ Tables 8 and 9>}

Black men were more likely to be employed in manufacturing in 1970. Because of that they were much more affected by de-industrialization. In 197056 percent of black men had manufacturing jobs in Detroit, 47 in Cleveland, and 37 in Chicago. By 2000 in these cities manufacturing employment of black men decreased by 30, 26, and 24 percentage points, respectively. More generally, while in 1970 in 10 out of 14 cities manufacturing employed the largest proportion of black workers, by 2000, as a result of de-industrialization, manufacturing lost its leading role in all cities except Detroit. In Detroit the proportion of black men employed in manufacturing has decreased from 56 percent in 1970 to 26 percent in 2000.

Not surprisingly, labor market conditions deteriorated more significantly in cities with high manufacturing concentration. In cities that were more diverse in terms of an industrial mix the results of de-industrialization were less dire. As we saw before, labor force participation of black men did not decrease nearly as dramatically in Atlanta and Washington as in Chicago and Detroit. 


\section{Role of Migration}

It is impossible to talk about changes in local labor markets of these 14 cities without discussing underlying population changes. As Table 10 shows, most southern cities, especially Houston and Atlanta, were growing between 1970 and 2000. In contrast, Eastern and Midwestern cities were either declining or experiencing a very slow growth at a rate well below overall U.S. growth rate.

\section{$<$ Table 10>}

Table 11, which documents population changes of black population between the decades, shows that a pattern of changes in black population does not always follow the overall changes in population. For example, between 1970 and 1980 when New York City lost 9 percent of its population, the black population there actually increased by 13 percent. The similar events occur in other declining cities as well. ${ }^{20}$ Thus, while manufacturing was losing its importance and labor market conditions were deteriorating, black population in these cities was increasing.

On the other hand, rapidly growing cities like Houston and Atlanta had large increases of black population as well. What sets Atlanta apart, however, is that black population there was growing even faster than overall population.

\section{$<$ Table 11 $>$}

Tables 12 and 13 report changes of the population of black and white men, respectively. As expected, changes in the population of black men in Table 12 are consistent with changes of

\footnotetext{
${ }^{20}$ It is tempting to explain these changes by recalling that one of the main demographic trends during 1970 s and 1980 s was a migration of white population away from urban centers. Readers are reminded, however, that the unit of analysis in this paper is a metropolitan area that includes a central city together with adjacent communities (usually counties). Thus, the observed phenomenon cannot be explained by white flight to the suburbs only.
} 
the black population in general in Table 11. It is interesting to compare changes in population of black and white men. While the population of black men was increasing in each of the three decades between 1970 and 2000 in almost all cities, the population of white men was decreasing. For example, in New York between 1980 and 1990 the population of black men grew by 23 percent. At the same time the population of white men has decreased by 31 percent. Other eastern and Midwestern cities had a similar experience. Even when white men population grows it does so it a lower rate than the population of black men. The 1970-1980 population increase in Los Angeles was 1 percent for white men and 24 percent for black men.

\section{$<$ Tables 12 and 13>}

Table 14 offers a different way to look at migration flows of blacks. It reports the proportion of black men in each city who were born in that state. Ideally, we would like to know how many men were born in a city they live but the data do not offer this information. In 1970 Southern cities had a very high proportion of black men who were born there. In Memphis, for example, 91 percent of black men were born either in Tennessee or Mississippi. In Atlanta 86 percent of black men population in 1970 was from Georgia. The difference between these two cities, however, is that while black population of Memphis stayed predominantly local throughout three decades, Atlanta had a steady inflow of migrants from other parts of the country. By 1980 proportion of "locals" declined to 73 percent; by 1990 to 55 percent; and in 2000 only 43 percent of black men living in Atlanta were born in Georgia. This "churning” of the population contributed to Atlanta having one of the highest average education attainments of black men. Recall also that in 2000 Atlanta had highest employment rate of black men and lowest unemployment rate. 


\section{<Table 14>}

Table 14 also shows that Midwestern cities had an opposite black population dynamic. In 1970 most black men living in these cities were born elsewhere. This was, of course, a result of the Great Migration in the earlier part of the century which brought blacks to the north. In 1970 only 28 percent of black residents of Detroit were born in Michigan. In Cleveland, Chicago, and St. Louis the proportions of "locals” were, respectively, 34, 36, and 37 percent. In the following three decades, however, the inflow significantly decreased bringing the proportion of black men in Detroit who were born in Michigan to 69 percent. The other cities experienced similar increases.

The picture of migration is somewhat similar, though less dramatic, in Philadelphia and Baltimore. In New York, the proportion of “locals” stayed pretty stable in 30-40 percent range.

In western cities, San Francisco and Los Angeles, only a small proportion of black men in 1970 were California natives (15 and 13 percent, respectively). By 2000 it has increased to 45 percent in San Francisco and 47 percent in Los Angeles.

Differences in migration are clearly related to differences in economic well-being of black men across cities. Cities that are doing well, like Atlanta, attract more educated workers looking for good job opportunities. Struggling cities have difficult time raising their levels of human capital because they cannot attract talented educated workers from other places and are losing their own educated population. 


\section{Changes in Family Structure}

Stable families are one of the important indicators of healthy communities. Table 15 shows the distribution of marital status of black men in each city in 1970, 1980, 1990, and 2000. There are three categories: married, divorced/separated/widowed, and never been married. Figure 4 compares changes in distributions between 1970 and 2000. The most striking finding is that marriage rates of black men went down dramatically between 1970 and 2000. In 1970, 71 to 83 percent of black men were married across different cities. Houston had the largest marriage rate, 83 percent. By 2000 only 31 to 54 percent of this group were married. ${ }^{21}$ The marriage rates dropped particularly low in western cities and in the Midwest. In 2000 only 31 percent of black men were married in San Francisco, 44 percent in Los Angeles, and only 42-45 percent in all Midwestern cities. Houston still had the highest proportion of married black men in 2000, but it was down to 54 percent. Atlanta had a second highest marriage rate of black men, 53 percent.

From Table 15 it appears that the largest decline happened between 1970 and 1980, followed by somewhat smaller decline between 1980 and 1990. The marriage rates then stayed essentially stable between 1990 and 2000.

\section{$<$ Table 15 and 16>}

Remarkably, as easy to see from Figure 4, divorce rates did not change much in most cities. Instead, the proportion of black men who have never been married increased dramatically, in some cities more than 5 times. In Memphis, for instance, only 6 percent of black men have never been married in 1970. In 200032 percent of black men in Memphis were in this group. In

\footnotetext{
${ }^{21}$ Table 16 presents similar statistics for white men. It shows that marriage rates of white men have declined as well but not as dramatically as marriage rates of black men. In 1970, 78-88 percent of white men 25-55 years old living in analyzed 14 cities were married. By 2000, the proportion of married white men has declined to 47-69 percent, depending on a city.
} 
San Francisco 49 percent of black men have never been married. In Midwestern cities proportion of black men who were never married increased from 7-11 percent in 1970 to 34-39 percent in 2000.

\section{$<$ Figure 4 $>$}

This trend describes alarming demographic changes in the black community. ${ }^{22}$ One direct consequence is that there are more single mothers and more children grow up in single parent households.

\section{Well-Being of the Children}

The paper thus far documented mainly negative developments in economic and social conditions of blacks between 1970 and 2000: increase in out of labor force and unemployment rates, decrease in relative annual incomes, insufficient progress in educational attainment, and decrease in marriage rates. One question that seems very important is how these changes affect well-being of the children? Has there been any progress in their welfare? To address this question in the most straight-forward way, we compare incomes distributions of white and black children's families. ${ }^{23}$ Comparison of incomes of families allows us to summarize the impact of

\footnotetext{
${ }^{22}$ There is a literature that that suggests that welfare payments structure discourages marriage (e.g. Duncan and Hoffman (1990) and Lichter, LeCelre, and McLaughlin (1991). Moffit (1997), however, reviews this literature and concludes that "considerable uncertainty surrounds this consensus because a sizable minority of the studies find no effect at all, because the magnitudes of the estimated effects vary widely, and because puzzling and unexplained differences exist across the studies by race and methodological approach." Black, McKinnish, and Sanders (2003) find that when low-skill workers have high-wage jobs (as did miners during a coal boom), welfare expenditure decrease partly because of the decline in single-parent households.

Charles and Luoh (forthcoming) present evidence that an increase in incarceration rates of black males negatively affected the marriage market for black women. It led to a shift of gains from marriage from women towards men. Our sample, however, does not include men who were in prison at a time of a survey. Thus, the estimated marriage rates are likely to be even lower if one includes incarcerated males.

${ }^{23}$ For this exercise, the income measure we use includes annual pre-tax income of a family from all sources, including social security and welfare payments and sources such as veterans' payments, unemployment
} 
changes in marriage rates and increase in single mother households, changes in labor force participation rates and wages, as well as capture the impact of economic progress of women. ${ }^{24}$

We consider a group of 8 to12 year old children, black and white. First, we compute an annual income distribution of white children's families. Then we calculate the $75^{\text {th }}$ percentile, the median, and the $25^{\text {th }}$ percentile of annual income distribution of black children's families. Finally, we determine the place of each of these quintiles of black family income distribution in the white family income distribution. The results are reported in Table 17. Consider Houston in 1970, for instance. As the table shows, the median of black children's family income distribution corresponds to a $12^{\text {th }}$ percentile of white children's family income distribution. It means that only 12 percent of white kids had family income below the level that was the median income of black kids' families. To put the other way, half of black kids have family income that was less than income of 88 percent of white kids' families. Similarly, the $25^{\text {th }}$ percentile of the "black distribution" corresponds to the $4^{\text {th }}$ percentile of the "white distribution". This means that 25 percent of black children were as poor as only bottom 4 percent of white children. The $75^{\text {th }}$ percentile of the "black distribution" corresponds to the $27^{\text {th }}$ percentile of the "white distribution”, which means that 73 percent of white kids were at least as rich as the top, rich, quarter of black kids.

In addition, Table 17 reports a ratio of median incomes of black and white families. For example, in Houston in 1970 the median income of black children’s families was only a half of median income of white children's families.

compensation, child support, and alimony. Incomes were recorded for all persons in a family who were 15 and older (14 and older in 1970 data).

${ }^{24}$ We do not study economic progress of black women in this paper, leaving this important topic to a future research. Stagnation of the economic progress of black men is likely to have behavioral responses from women. Charles and Luoh (forthcoming) find, for example, that black women who face marriage markets with reduced quality of potential spouses increase their schooling and labor supply. 
Table 17 paints a bleak picture. In all cities the median annual income of black children's families is only about one half of the median annual income of white children's families. What is more, this ratio did not increase in any of the 14 cities over the 1970-2000 period. ${ }^{25}$ In fact, in 10 out of 14 cities the ratio has decreased, meaning that median income of black children's families decreased relative to median income of white children's families. In San Francisco it decreased from 0.6 in 1970 to 0.3 in 2000. In Chicago the ratio of black and white median incomes decreased from 0.6 in 1970 to 0.4 in 2000.

Furthermore, where does the median income of black children's families fit into income distribution of white children's families? In 2000 the situation was the best in New York where the median of the "black" distribution corresponds to the $23^{\text {rd }}$ percentile of the "white" distribution. Thus, 50 percent of black children in New York had financial resources that are below than those of 77 percent of white children. The things are even worse in the rest of the cities. In 2000 the median annual income of black children’s families corresponds to only 11-17 percentile of "white" distribution, depending on the city.

The situation at the top and bottom quartiles of the distribution of family income of black children is not better than in the middle of the distribution. In 2000 the $75^{\text {th }}$ percentile of the "black" distribution still corresponds to only 33-43th percentile of the "white distribution". Perhaps even more alarming, 25 percent of black children have family financial resources that are as low as financial resources of the poorest 3-7 percent of white families. To sum up, there was no progress in a financial well-being of black children, relative to white children, between 1970 and 2000.

\footnotetext{
${ }^{25}$ We also looked at ratios of various other percentiles of the two distributions. The results were the same - there is no change in ratios over the years.
} 


\section{$<$ Table 17>}

\section{Concluding Remarks}

More than 35 years after the Civil Rights Act the economic status of black men is still much worse than those of white men. What is more, there appears to be virtually no progress of black men in the labor markets. Some important indicators, such as out of the labor force rates and relative annual earnings, have actually become worse. Social structure and families of black population are also negatively affected.

This paper does not attempt to determine why there was stagnation, and even a reversal, of the economic progress of African-Americans between 1970 and $2000 .{ }^{26}$ Instead, the main goal of this paper was to describe changes in various economic conditions of black men and their families at a city level. The second goal was to compare changes across the cities.

While overall picture is rather bleak, there are clear differences between cities. Industrial cities in the Midwest (Chicago, Detroit, Cleveland, and St. Louis) experienced more serious deterioration of the labor markets precisely because they used to be predominantly manufacturing cities. With the decline of the importance of manufacturing and a move to hightech and service industries, low-educated labor force of these cities faced tough labor market conditions. This resulted in high levels of unemployment. More people became discouraged about their job finding prospects and dropped out of the labor force completely. Family structure was disrupted as well as more and more black men chose not to marry. More black children are growing up in single mother households. The economic well-being of children has not improved since 1970.

\footnotetext{
${ }^{26}$ Neal (2008) presents a short summary of possible explanations and a discussion of several related studies.
} 
Most eastern and western city in the study showed a decline similar to that of Midwestern cities but of a somewhat lesser degree.

Southern cities, on the other hand, did see some economic progress of black men, mostly between 1970 and 1980. These improvements together with the reversal of economic progress in the Midwest resulted in more uniform conditions of black men in 2000 than they were in 1970. Educational attainment of black men in the South, in particular, has increased dramatically compared to 1970.

Atlanta and Washington stand out on a number of characteristics. They had the highest employment rates of black men in 2000 as well as low unemployment and out of the labor force rates. They also had the highest proportion of black men who went to college and those with a university degree and above. One of the reasons these two cities fair better is their industrial structure. Atlanta has a very vibrant mix of industries and never relied heavily on manufacturing. Washington has a high proportion of service and stable government jobs. These cities are able to attract high-skilled educated workers from other parts of the country.

Despite remarkable changes in the society when it comes to racial acceptance and equality, the evidence presented in this paper reveals that significant racial disparities remain in education and labor market outcomes. A better understanding of underlying causes of the observed economic stagnation and a design of policies that would help improve social and economic status of African-Americans is an important topic for future research. 


\section{Appendix 1: Data and Variables Description}

Educational Attainment Five education categories were generated: did not finish high school, high school diploma of GED, some college but no bachelor's degree, bachelor's degree, and higher than a bachelor's degree.

Employment Status Three employment status categories were generated: has a job, unemployed, and not in labor force.

Definition of Industry Variable Because of the relatively small size of the sample, it was necessary to combine Census-defined industries and occupations into larger groups. Eleven industry categories were generated according to Department of Labor's Standard Industrial Classification. The industrial categories are agriculture, forestry and fishing; mining; construction; manufacturing; transportation/communications/utility; wholesale trade; retail trade; finance, insurance, and real estate; service; public administration; and other. This last category represents military personnel, temporary unemployed workers, and people with missing information. The 1990 Census Bureau industrial classification scheme is used for all years for consistency. Whole sale and retail are combine into a category called "sales”. Since only a very small fraction of people living in urban areas are employed in agriculture, forestry and fishing, and mining, these three categories were combined with "other” category for presentation purposes. At the end, there are eight industrial categories.

Marital Status Three marital status categories are married; separated, divorced, or widowed; and never married. 
Non-Migrant Indicator A non-migrant indicator variable was created as follows. It is equal to one if a person satisfied one of the following: born in Georgia and lives in Atlanta; born in Maryland and lives in Baltimore; born in Illinois and lives in Chicago; born in Ohio and lives in Cleveland; born in Michigan and lives in Detroit; born in Texas and lives in Houston; born in California and lives in Los Angeles; born in Tennessee and lives in Memphis; born in Mississippi and lives in Memphis; born in Louisiana and lives in New Orleans; born in New York and lives in New York; born in Pennsylvania and lives in Philadelphia; born in New Jersey and lives in Philadelphia; born in Missouri and lives in St. Louis; born in California and lives in San Francesco; born in Washington DC and lives in Washington DC; born in Maryland and lives in Washington DC, as well as born in Virginia and lives in Washington DC. The indicator was set to zero for all other persons.

\section{MSA Population}

MSA population data for 1970, 1980, 1990 and 1999 are downloaded from the Population database, Real Estate Center at Texas A\&M University. It is calculated based on U.S. Census data. For consistency, 1999 definition of MSAs were used.

\section{MSA Black Population}

The data source is The Population Estimates Archives, U.S. Census Bureau. The archives provide data on a county level. County-level data were aggregated into MSA level data according to 1999 MSA definitions. 


\section{Appendix 2: Estimation}

\section{Black-White Annual Earnings Gap}

A simple matching estimator was used to calculate, for each metropolitan area $j$, the black-white ratio of annual earnings. Intuitively, black men were "matched” with white men based on their age and education. More precisely, let $b$ index black individuals and $w$ index white individuals, and let $x_{i}$ be the age-education combination of individual $i$, e.g. "high-school educated man aged 31”. Let $y_{i}$ be the annual earnings of individual $i$, and let $E\left(y_{\{b, i\}} \mid x\right)$ be the expected value of the annual earnings of that (black) individual given that his age-education combination is $x$. There are four education categories and six age intervals: 25-30, 31-35, 36-40, 41-45, 46-50, and 51-55 years of age.

Our interest then is in

Ratio $_{j}=\sum_{x=25}^{55}=\left[\frac{E_{j}\left(\left.y_{\{b, i\}}\right|^{x}\right)}{E_{j}\left(\left.y_{\{w, i\}}\right|^{x}\right)}\right] f_{b(x)}$,

where $f_{b(x)}$ is p.d.f. of age-education combinations among black workers in all cities. The equation is then directly estimated for each city by calculating the conditional means at each point in the distribution of covariates and then taking a weighted average. Observations with zero values are included in the calculations.

\section{Average Annual Weeks and Average Weekly Hours of Work}

One of the limitations of the data is that in 1970 the Census asked only for hours and weeks of work on intervals. Black et al (2009) compute the average weeks and hours conditional 
on being in the relevant category using 1980 Census data. In this paper, the values from Black et al (2009) were used to make imputations for non-zero categories as follows:

\begin{tabular}{|l|c|l|c|}
\hline Interval & Imputed weeks & Interval & Imputed hours \\
\hline $1-13$ weeks & 1.1 & $1-14$ hours & 8.57 \\
\hline $14-26$ weeks & 21.4 & $15-29$ hours & 21.95 \\
\hline $27-39$ weeks & 33.3 & $30-34$ hours & 30.64 \\
\hline $40-47$ weeks & 43.4 & $35-39$ & 36.35 \\
\hline $48-49$ weeks & 48.3 & 40 hours & 40 \\
\hline $50-52$ weeks & 51.8 & $41-48$ hours & 45.46 \\
\hline & & $49-59$ hours & 51.41 \\
\hline
\end{tabular}

Then, for each city, the weighted average annual weeks and weekly hours of work were calculated conditional on age and education. The distribution of age-education combinations across all cities was used for weighting. Observations with zero values are included in the calculations. 


\section{References}

Altonji, Joseph G., and Blank, Rebecca. “Race and Gender in the Labor Market”, in Orley Ashenfelter and David Card, eds., Handbook of Labor Economics, North Holland.1999, Chapter 48.

Bound, John and Freeman, Richard B. "What Went Wrong? The Erosion of Relative Earnings and Employment Among Young Black Men in the 1980s” The Quarterly Journal of Economics, Vol. 107 (1), Feb. 1992, 201-232.

Bound, John and Holzer, Harry J. "Industrial Shifts, Skill Levels, and the Labor Market for White and Black Males”. The Review of Economics and Statistics, 75(3), August 1993, 387-96.

Bound, John and Johnson, George. “Changes in the Structure of Wages in the 1980’s: An Evaluation of Alternative Explanations”. The American Economic Review, Vol 82(3). June 1992, 371-392.

Black, Dan; Kolesnikova, Natalia; Sanders, Seth; and Taylor, Lowell. "The role of location in evaluating racial wage disparity”. Federal Reserve Bank of St. Louis Working Paper 2009-043A.

Black, Dan A.; McKinnish, Terra G. ; and Sanders, Seth G. "Does the Availability of High-wage Jobs for Low-skilled Men Affect Welfare Expenditures? Evidence from Shocks to the Steel and Coal Industries” Journal of Public Economics, 87(9-10), September 2003, 1921-42.

Calvó-Armengol, Antoni and Jackson, Matthew O. “The Effects of Social Networks on Employment and Inequality” The American Economic Review, Vol. 94(3), June 2004, 426-454. 
Charles, Kerwin and Luoh, Ming Ching, "Male Incarceration, the Marriage Market and Female Outcomes.” Forthcoming in Review of Economics and Statistics.

Metropolitan Population Database, Real Estate Center, Texas A\&M University. http://recenter.tamu.edu/data/popm/

Duncan, Greg J., and Hoffman, Saul D. “Welfare Benefits, Economic Opportunities, and Out-ofWedlock Births among Black Teenage Girls.” Demography 27(4), November 1990, 519-535.

Harry J. Holzer “Informal Job Search and Black Youth Unemployment” The American Economic Review, 77(3), June 1987, 446-52.

Lichter, Daniel T.; LeClere, Felicia B.; and McLaughlin, Diane K. “Local Marriage Markets and the Marital Behavior of Black and White Women.” The American Journal of Sociology, 96(4), January, 1991, 843-67.

Moffitt, Robert A. "The Effect of Welfare on Marriage and Fertility: What Do We Know and What Do We Need to Know?” Institute for Research on Poverty Discussion Paper no. 1153-97.

Neal Derek, “Why Has Black-White Skill Convergence Stopped?” in Eric Hanushek and Finis Welch, eds., Handbook of theEconomics of Education, Chapter 9, Elsevier. 2006.

Neal, Derek, "Black-white labour market inequality in the United States," in Steven Durlauf and Lawrence Blume, eds., New Palgrave Dictionary of Economics, 2008.

Population Estimates Archives, U.S. Census Bureau. http://www.census.gov/popest/archives/ 
Ruggles, Steven; Alexander, J. Trent; Genadek, Katie; Goeken, Ronald; Schroeder, Matthew B.; and Sobek, Matthew. Integrated Public Use Microdata Series: Version 5.0 [Machine-readable database]. Minneapolis: University of Minnesota, 2010.

Western, Bruce. “Punishment and Inequality in America.” 2006, New York: Russell Sage Foundation. 


\section{Table 1. Black-White Weekly Wages Ratios for Men, \%}

\begin{tabular}{|c|c|c|c|c|}
\hline Year & 1970 & 1980 & 1990 & 2000 \\
\hline \multicolumn{5}{|l|}{ Southern } \\
\hline Houston & 65 & 76 & 74 & 72 \\
\hline Memphis & 63 & 73 & 71 & 78 \\
\hline Atlanta & 62 & 75 & 75 & 78 \\
\hline New Orleans & 63 & 73 & 74 & 75 \\
\hline Washington & 72 & 80 & 81 & 83 \\
\hline \multicolumn{5}{|l|}{ Eastern } \\
\hline New York & 75 & 76 & 77 & 78 \\
\hline Philadelphia & 79 & 77 & 77 & 77 \\
\hline Baltimore & 71 & 78 & 76 & 79 \\
\hline \multicolumn{5}{|l|}{ Midwestern } \\
\hline St. Louis & 74 & 77 & 73 & 77 \\
\hline Cleveland & 76 & 82 & 80 & 77 \\
\hline Chicago & 75 & 75 & 74 & 74 \\
\hline Detroit & 81 & 83 & 81 & 78 \\
\hline \multicolumn{5}{|l|}{ Western } \\
\hline Los Angeles & 74 & 77 & 81 & 80 \\
\hline San Francisco & 78 & 79 & 82 & 80 \\
\hline
\end{tabular}

Note: The table is adapted from Black et al (2009). For convenience, log differences of positive weekly wages of black and white men were converted into ratios. 


\section{Table 2. Black-White Annual Earnings Ratios for Men, \%}

\begin{tabular}{|c|c|c|c|c|}
\hline Year & 1970 & 1980 & 1990 & 2000 \\
\hline \multicolumn{5}{|l|}{ Southern } \\
\hline Houston & 59 & 67 & 61 & 59 \\
\hline Memphis & 52 & 60 & 56 & 66 \\
\hline Atlanta & 56 & 64 & 66 & 66 \\
\hline New Orleans & 57 & 63 & 60 & 65 \\
\hline Washington & 62 & 71 & 70 & 72 \\
\hline \multicolumn{5}{|l|}{ Eastern } \\
\hline New York & 68 & 64 & 60 & 58 \\
\hline Philadelphia & 72 & 63 & 63 & 61 \\
\hline Baltimore & 66 & 65 & 65 & 67 \\
\hline \multicolumn{5}{|l|}{ Midwestern } \\
\hline St. Louis & 66 & 63 & 59 & 62 \\
\hline Cleveland & 70 & 70 & 62 & 63 \\
\hline Chicago & 69 & 62 & 56 & 55 \\
\hline Detroit & 71 & 66 & 60 & 63 \\
\hline \multicolumn{5}{|l|}{ Western } \\
\hline Los Angeles & 66 & 66 & 64 & 62 \\
\hline San Francisco & 68 & 63 & 62 & 62 \\
\hline
\end{tabular}

Note: Authors' calculations. See Appendix 2 for details. The calculation includes individuals with zero earnings. 
Table 3: Average Annual Weeks of Work by Black Men

\begin{tabular}{l|cccc}
\hline Year & $\mathbf{1 9 7 0}$ & $\mathbf{1 9 8 0}$ & $\mathbf{1 9 9 0}$ & $\mathbf{2 0 0 0}$ \\
\hline Southern & & & & \\
Houston & 46 & 41 & 38 & 39 \\
Memphis & 41 & 39 & 39 & 38 \\
Atlanta & 44 & 40 & 41 & 41 \\
New Orleans & 43 & 39 & 35 & 36 \\
Washington & 46 & 41 & 42 & 41 \\
\hline Eastern & & & & \\
New York & 43 & 37 & 36 & 35 \\
Philadelphia & 45 & 36 & 37 & 37 \\
Baltimore & 45 & 39 & 39 & 39 \\
\hline Midwestern & & & & 37 \\
St. Louis & 44 & 38 & 36 & 37 \\
Cleveland & 46 & 38 & 34 & 34 \\
Chicago & 45 & 37 & 35 & 35 \\
Detroit & 45 & 35 & 33 & 34 \\
\hline Western & & & & 33 \\
Los Angeles & 43 & 37 & 35 & 38 \\
San Francisco & 42 & 35 & 32 & 38 \\
\hline United States & 44 & 39 & & \\
\hline
\end{tabular}

Note: Authors' calculations. See Appendix 2 for details. The calculation includes individuals with zero weeks of work. 
Table 4: Average Weekly Hours of Work by Black Men

\begin{tabular}{l|llll}
\hline Year & $\mathbf{1 9 7 0}$ & $\mathbf{1 9 8 0}$ & $\mathbf{1 9 9 0}$ & $\mathbf{2 0 0 0}$ \\
\hline Southern & & & & \\
Houston & 38 & 36 & 35 & 36 \\
Memphis & 33 & 34 & 34 & 35 \\
Atlanta & 34 & 35 & 37 & 37 \\
New Orleans & 33 & 34 & 33 & 33 \\
Washington & 37 & 36 & 37 & 37 \\
\hline Eastern & & & & \\
New York & 34 & 31 & 32 & 31 \\
Philadelphia & 35 & 32 & 34 & 34 \\
Baltimore & 35 & 34 & 35 & 35 \\
\hline Midwestern & & & & \\
St. Louis & 33 & 33 & 33 & 34 \\
Cleveland & 35 & 34 & 31 & 34 \\
Chicago & 34 & 32 & 32 & 31 \\
Detroit & 33 & 32 & 31 & 33 \\
\hline Western & & & & \\
Los Angeles & 33 & 33 & 29 & 31 \\
San Francisco & 31 & 31 & 34 & 34 \\
\hline United States & 34 & 34 &
\end{tabular}

Note: Authors' calculations. See Appendix 2 for details. The calculation includes individuals with zero weekly hours of work. 


\section{Table 5: Employment Status of Black Men, \%}

\begin{tabular}{|c|c|c|c|c|c|c|c|c|c|}
\hline Year & 1970 & 1980 & 1990 & 2000 & Year & 1970 & 1980 & 1990 & 2000 \\
\hline $\begin{array}{l}\text { Southern } \\
\text { Houston }\end{array}$ & & & & & Midwestern & & & & \\
\hline $\begin{array}{l}\text { Houston } \\
\text { Has a job }\end{array}$ & 92 & 89 & 79 & 77 & $\begin{array}{l}\text { St. Louls } \\
\text { Has a job }\end{array}$ & 83 & 74 & 71 & 72 \\
\hline Unemployed & 2 & 3 & 10 & 6 & Unemployed & 8 & 13 & 13 & 7 \\
\hline $\begin{array}{l}\text { Not in Labor Force } \\
\text { Memphis }\end{array}$ & 6 & 8 & 11 & 17 & $\begin{array}{l}\text { Not in Labor Force } \\
\text { Cleveland }\end{array}$ & 10 & 13 & 16 & 21 \\
\hline Has a job & 85 & 79 & 79 & 74 & Has a job & 85 & 75 & 68 & 72 \\
\hline Unemployed & 3 & 9 & 7 & 6 & Unemployed & 6 & 11 & 13 & 8 \\
\hline $\begin{array}{l}\text { Not in Labor Force } \\
\text { Atlanta }\end{array}$ & 11 & 13 & 14 & 20 & $\begin{array}{l}\text { Not in Labor Force } \\
\text { Chicago }\end{array}$ & 9 & 14 & 18 & 20 \\
\hline Has a job & 87 & 82 & 84 & 81 & Has a job & 88 & 75 & 71 & 69 \\
\hline Unemployed & 3 & 7 & 7 & 4 & Unemployed & 4 & 10 & 13 & 9 \\
\hline $\begin{array}{l}\text { Not in Labor Force } \\
\text { New Orleans }\end{array}$ & 10 & 11 & 9 & 15 & $\begin{array}{l}\text { Not in Labor Force } \\
\text { Detroit }\end{array}$ & 8 & 14 & 16 & 22 \\
\hline Has a job & 84 & 80 & 71 & 71 & Has a job & 86 & 65 & 66 & 69 \\
\hline Unemployed & 4 & 6 & 10 & 6 & Unemployed & 7 & 19 & 15 & 8 \\
\hline Not in Labor Force & 12 & 14 & 18 & 23 & Not in Labor Force & 7 & 16 & 19 & 23 \\
\hline Washington & & & & & Western & & & & \\
\hline Has a job & 92 & 85 & 87 & 81 & Los Angeles & & & & \\
\hline Unemployed & 1 & 5 & 5 & 5 & Has a job & 83 & 78 & 76 & 70 \\
\hline Not in Labor Force & 7 & 9 & 8 & 14 & Unemployed & 7 & 8 & 9 & 9 \\
\hline $\begin{array}{l}\text { Eastern } \\
\text { New York }\end{array}$ & & & & & $\begin{array}{l}\text { Not in Labor Force } \\
\text { San Francisco }\end{array}$ & 10 & 14 & 15 & 21 \\
\hline Has a job & 86 & 77 & 76 & 71 & Has a job & 83 & 76 & 73 & 71 \\
\hline Unemployed & 3 & 8 & 9 & 7 & Unemployed & 7 & 9 & 7 & 7 \\
\hline Not in Labor Force & 10 & 15 & 15 & 22 & Not in Labor Force & 11 & 15 & 21 & 22 \\
\hline Philadelphia & & & & & United States & & & & \\
\hline Has a job & 86 & 74 & 76 & 72 & & & & & \\
\hline Unemployed & 5 & 10 & 10 & 8 & Has a Job & 87 & 79 & 77 & 74 \\
\hline Not in Labor Force & 9 & 16 & 14 & 21 & & & & & \\
\hline Baltimore & & & & & Unemployed & 4 & 8 & 9 & 6 \\
\hline Has a job & 87 & 78 & 78 & 74 & & & & & \\
\hline Unemployed & 4 & 8 & 8 & 7 & Not in Labor Force & 9 & 13 & 14 & 19 \\
\hline Not in Labor Force & 9 & 14 & 14 & 19 & & & & & \\
\hline
\end{tabular}

Note: Authors' calculations. See Appendix 1 for details. 
Table 6: Educational Attainment of Black Men, \%

\begin{tabular}{|c|c|c|c|c|c|c|c|c|c|}
\hline Year & 1970 & 1980 & 1990 & 2000 & Year & 1970 & 1980 & 1990 & 2000 \\
\hline $\begin{array}{l}\text { Southern } \\
\text { Houston }\end{array}$ & & & & & $\begin{array}{l}\text { Midwestern } \\
\text { St. Louis }\end{array}$ & & & & \\
\hline Less than high school & 63 & 31 & 23 & 16 & Less than high school & 59 & 37 & 26 & 20 \\
\hline High school or GED & 22 & 35 & 31 & 30 & High school or GED & 25 & 33 & 32 & 33 \\
\hline Some college, no degree & 10 & 20 & 28 & 34 & Some college, no degree & 11 & 20 & 29 & 34 \\
\hline Bachelor's degree & 2 & 8 & 13 & 15 & Bachelor's degree & 2 & 6 & 9 & 10 \\
\hline Above a bachelor's degree & 3 & 7 & 5 & 5 & Above a bachelor's degree & 3 & 5 & 4 & 4 \\
\hline Memphis & & & & & Cleveland & & & & \\
\hline Less than high school & 77 & 44 & 29 & 22 & Less than high school & 55 & 35 & 29 & 20 \\
\hline High school or GED & 15 & 34 & 34 & 36 & High school or GED & 33 & 41 & 35 & 37 \\
\hline Some college, no degree & 4 & 14 & 27 & 30 & Some college, no degree & 8 & 16 & 27 & 30 \\
\hline Bachelor's degree & 2 & 5 & 8 & 10 & Bachelor's degree & 2 & 5 & 6 & 9 \\
\hline Above a bachelor's degree & 1 & 3 & 3 & 3 & || Above a bachelor's degree & 2 & 4 & 4 & 4 \\
\hline Atlanta & & & & & |Chicago & & & & \\
\hline Less than high school & 64 & 34 & 21 & 13 & Less than high school & 52 & 37 & 26 & 19 \\
\hline High school or GED & 26 & 38 & 32 & 29 & || High school or GED & 31 & 34 & 29 & 28 \\
\hline Some college, no degree & 5 & 15 & 28 & 34 & Some college, no degree & 11 & 20 & 32 & 35 \\
\hline Bachelor's degree & 2 & 8 & 14 & 17 & Bachelor's degree & 3 & 5 & 9 & 12 \\
\hline Above a bachelor's degree & 2 & 5 & 6 & 6 & Above a bachelor's degree & 2 & 4 & 4 & 5 \\
\hline New Orleans & & & & & Detroit & & & & \\
\hline Less than high school & 70 & 43 & 34 & 26 & Less than high school & 58 & 36 & 28 & 21 \\
\hline High school or GED & 19 & 32 & 28 & 33 & || High school or GED & 30 & 36 & 30 & 34 \\
\hline Some college, no degree & 7 & 16 & 26 & 29 & Some college, no degree & 7 & 19 & 31 & 32 \\
\hline Bachelor's degree & 3 & 5 & 8 & 9 & Bachelor's degree & 2 & 5 & 7 & 9 \\
\hline Above a bachelor's degree & 2 & 3 & 3 & 3 & Above a bachelor’s degree & 3 & 4 & 4 & 5 \\
\hline Washington & & & & & Eastern & & & & \\
\hline Less than high school & 47 & 28 & 20 & 13 & New York & & & & \\
\hline High school or GED & 33 & 36 & 30 & 29 & Less than high school & 51 & 33 & 30 & 22 \\
\hline Some college, no degree & 9 & 19 & 28 & 31 & High school or GED & 35 & 38 & 29 & 29 \\
\hline Bachelor's degree & 6 & 8 & 14 & 17 & Some college, no degree & 8 & 17 & 27 & 30 \\
\hline Above a bachelor's degree & 6 & 9 & 8 & 9 & Bachelor's degree & 3 & 6 & 10 & 13 \\
\hline Western & & & & & Above a bachelor's degree & 3 & 5 & 5 & 6 \\
\hline $\begin{array}{l}\text { Los Angeles } \\
\text { Less than high school }\end{array}$ & 38 & 21 & 18 & 15 & \begin{tabular}{|l} 
Philadelphia \\
Less than high school
\end{tabular} & 56 & 36 & 28 & 19 \\
\hline High school or GED & 35 & 36 & 26 & 25 & High school or GED & 31 & 41 & 36 & 38 \\
\hline Some college, no degree & 19 & 29 & 38 & 40 & Some college, no degree & 7 & 13 & 23 & 28 \\
\hline Bachelor's degree & 4 & 7 & 13 & 14 & Bachelor's degree & 3 & 5 & 9 & 11 \\
\hline Above a bachelor's degree & 4 & 7 & 6 & 6 & || Above a bachelor's degree & 3 & 5 & 4 & 5 \\
\hline San Francisco & & & & & Baltimore & & & & \\
\hline Less than high school & 42 & 19 & 18 & 16 & Less than high school & 66 & 44 & 29 & 20 \\
\hline High school or GED & 32 & 34 & 23 & 24 & High school or GED & 23 & 32 & 32 & 34 \\
\hline Some college, no degree & 17 & 30 & 37 & 37 & Some college, no degree & 5 & 15 & 25 & 29 \\
\hline Bachelor's degree & 5 & 8 & 13 & 14 & Bachelor's degree & 4 & 4 & 9 & 11 \\
\hline Above a bachelor's degree & 4 & 9 & 9 & 9 & Above a bachelor's degree & 3 & 5 & 5 & 6 \\
\hline
\end{tabular}


Table 7: Educational Attainment of White Men, \%

\begin{tabular}{|c|c|c|c|c|c|c|c|c|c|}
\hline Year & 1970 & 1980 & 1990 & 2000 & Year & 1970 & 1980 & 1990 & 2000 \\
\hline $\begin{array}{l}\text { Southern } \\
\text { Houston }\end{array}$ & & & & & $\begin{array}{l}\text { Midwestern } \\
\text { St. Louis }\end{array}$ & & & & \\
\hline Less than high school & 32 & 13 & 9 & 7 & Less than high school & 37 & 18 & 11 & 8 \\
\hline High school or GED & 25 & 26 & 20 & 19 & High school or GED & 35 & 35 & 27 & 25 \\
\hline Some college, no degree & 17 & 23 & 30 & 30 & Some college, no degree & 10 & 19 & 30 & 32 \\
\hline Bachelor's degree & 14 & 21 & 27 & 30 & Bachelor's degree & 10 & 14 & 21 & 23 \\
\hline Above a bachelor's degree & 11 & 18 & 14 & 14 & Above a bachelor’s degree & 8 & 14 & 11 & 12 \\
\hline Memphis & & & & & Cleveland & & & & \\
\hline Less than high school & 29 & 14 & 8 & 7 & Less than high school & 32 & 18 & 11 & 8 \\
\hline High school or GED & 38 & 32 & 21 & 21 & High school or GED & 36 & 37 & 30 & 30 \\
\hline Some college, no degree & 13 & 22 & 34 & 33 & Some college, no degree & 13 & 18 & 28 & 31 \\
\hline Bachelor's degree & 11 & 16 & 24 & 26 & Bachelor's degree & 10 & 15 & 19 & 21 \\
\hline Above a bachelor's degree & 9 & 15 & 13 & 13 & Above a bachelor's degree & 8 & 13 & 11 & 11 \\
\hline Atlanta & & & & & Chicago & & & & \\
\hline Less than high school & 31 & 16 & 9 & 8 & Less than high school & 30 & 15 & 9 & 6 \\
\hline High school or GED & 28 & 27 & 20 & 20 & High school or GED & 33 & 32 & 22 & 20 \\
\hline Some college, no degree & 17 & 21 & 28 & 27 & Some college, no degree & 16 & 20 & 29 & 29 \\
\hline Bachelor's degree & 14 & 20 & 29 & 30 & Bachelor's degree & 12 & 17 & 25 & 29 \\
\hline Above a bachelor's degree & 9 & 16 & 14 & 14 & Above a bachelor’s degree & 10 & 16 & 15 & 17 \\
\hline New Orleans & & & & & Detroit & & & & \\
\hline Less than high school & 36 & 17 & 11 & 13 & Less than high school & 35 & 19 & 12 & 9 \\
\hline High school or GED & 29 & 30 & 23 & 25 & High school or GED & 34 & 35 & 27 & 26 \\
\hline Some college, no degree & 14 & 19 & 29 & 29 & Some college, no degree & 13 & 21 & 34 & 34 \\
\hline Bachelor's degree & 11 & 16 & 22 & 21 & Bachelor's degree & 9 & 12 & 17 & 20 \\
\hline Above a bachelor's degree & 10 & 17 & 15 & 12 & Above a bachelor's degree & 9 & 13 & 9 & 11 \\
\hline Washington & & & & & Eastern & & & & \\
\hline Less than high school & 20 & 9 & 6 & 5 & New York & & & & \\
\hline High school or GED & 27 & 21 & 16 & 15 & Less than high school & 32 & 17 & 10 & 7 \\
\hline Some college, no degree & 15 & 16 & 23 & 22 & High school or GED & 32 & 28 & 20 & 18 \\
\hline Bachelor's degree & 14 & 20 & 29 & 31 & Some college, no degree & 12 & 17 & 22 & 22 \\
\hline Above a bachelor's degree & 24 & 33 & 27 & 27 & Bachelor's degree & 11 & 17 & 25 & 30 \\
\hline $\begin{array}{l}\text { Western } \\
\text { Los Angeles }\end{array}$ & & & & & $\begin{array}{l}\text { Above a bachelor’s degree } \\
\text { Philadelphia }\end{array}$ & 13 & 22 & 22 & 24 \\
\hline Less than high school & 21 & 11 & 8 & 6 & Less than high school & 34 & 19 & 10 & 7 \\
\hline High school or GED & 33 & 27 & 17 & 15 & High school or GED & 36 & 37 & 31 & 29 \\
\hline Some college, no degree & 22 & 27 & 34 & 33 & Some college, no degree & 11 & 15 & 23 & 25 \\
\hline Bachelor's degree & 11 & 16 & 24 & 28 & Bachelor's degree & 11 & 15 & 22 & 25 \\
\hline Above a bachelor's degree & 13 & 19 & 16 & 17 & Above a bachelor’s degree & 9 & 15 & 13 & 15 \\
\hline San Francisco & & & & & Baltimore & & & & \\
\hline Less than high school & 19 & 8 & 5 & 3 & Less than high school & 41 & 23 & 12 & 9 \\
\hline High school or GED & 32 & 25 & 13 & 10 & High school or GED & 30 & 32 & 26 & 24 \\
\hline Some college, no degree & 20 & 25 & 30 & 25 & Some college, no degree & 11 & 16 & 26 & 28 \\
\hline Bachelor's degree & 14 & 18 & 30 & 37 & Bachelor's degree & 10 & 14 & 21 & 24 \\
\hline Above a bachelor's degree & 15 & 24 & 23 & 25 & Above a bachelor's degree & 8 & 15 & 14 & 16 \\
\hline
\end{tabular}


Table 8: Employment Distribution by Industry, All Men, \%

\begin{tabular}{|c|c|c|c|c|c|c|c|c|c|}
\hline Year & 1970 & 1980 & 1990 & 2000 & Year & 1970 & 1980 & 1990 & 2000 \\
\hline $\begin{array}{l}\text { Southern } \\
\text { Houston }\end{array}$ & & & & & $\begin{array}{l}\text { Midwestern } \\
\text { St. Louis }\end{array}$ & & & & \\
\hline Construction & 14 & 15 & 13 & 14 & Construction & 8 & 8 & 10 & 11 \\
\hline Manufacturing & 28 & 24 & 18 & 16 & Manufacturing & 37 & 32 & 26 & 20 \\
\hline Transportation & 11 & 10 & 10 & 10 & Transportation & 12 & 12 & 11 & 11 \\
\hline Sale & 18 & 17 & 20 & 18 & Sale & 16 & 15 & 17 & 16 \\
\hline Finance & 3 & 4 & 5 & 4 & Finance & 3 & 4 & 5 & 5 \\
\hline Service & 16 & 18 & 22 & 24 & Service & 13 & 17 & 20 & 25 \\
\hline Public Administration & 3 & 3 & 3 & 3 & Public Administration & 6 & 6 & 5 & 4 \\
\hline Other & 7 & 9 & 9 & 10 & Other & 5 & 6 & 6 & 7 \\
\hline Memphis & & & & & Cleveland & & & & \\
\hline Construction & 7 & 8 & 9 & 9 & Construction & 8 & 8 & 8 & 10 \\
\hline Manufacturing & 25 & 22 & 16 & 13 & Manufacturing & 45 & 39 & 28 & 26 \\
\hline Transportation & 13 & 14 & 14 & 17 & Transportation & 10 & 10 & 10 & 8 \\
\hline Sale & 20 & 19 & 20 & 18 & Sale & 15 & 14 & 17 & 15 \\
\hline Finance & 4 & 5 & 5 & 4 & Finance & 4 & 4 & 5 & 5 \\
\hline Service & 17 & 18 & 22 & 24 & Service & 13 & 17 & 21 & 23 \\
\hline Public Administration & 6 & 6 & 6 & 5 & Public Administration & 4 & 4 & 4 & 5 \\
\hline Other & 8 & 7 & 9 & 9 & Other & 2 & 4 & 7 & 7 \\
\hline Atlanta & & & & & Chicago & & & & \\
\hline Construction & 10 & 9 & 11 & 12 & Construction & 8 & 8 & 8 & 10 \\
\hline Manufacturing & 26 & 20 & 15 & 14 & Manufacturing & 37 & 31 & 23 & 20 \\
\hline Transportation & 12 & 14 & 13 & 13 & Transportation & 12 & 12 & 11 & 11 \\
\hline Sale & 21 & 20 & 22 & 19 & Sale & 17 & 16 & 18 & 16 \\
\hline Finance & 6 & 6 & 7 & 6 & Finance & 4 & 6 & 7 & 7 \\
\hline Service & 16 & 20 & 23 & 25 & Service & 15 & 19 & 23 & 26 \\
\hline Public Administration & 5 & 6 & 5 & 4 & Public Administration & 4 & 5 & 4 & 4 \\
\hline Other & 4 & 5 & 4 & 6 & Other & 3 & 5 & 6 & 7 \\
\hline New Orleans & & & & & Detroit & & & & \\
\hline Construction & 11 & 12 & 9 & 12 & Construction & 7 & 6 & 8 & 9 \\
\hline Manufacturing & 20 & 14 & 12 & 12 & Manufacturing & 51 & 45 & 35 & 33 \\
\hline Transportation & 16 & 15 & 12 & 11 & Transportation & 8 & 8 & 7 & 8 \\
\hline Sale & 18 & 18 & 19 & 17 & Sale & 13 & 13 & 16 & 15 \\
\hline Finance & 6 & 4 & 4 & 4 & Finance & 3 & 3 & 4 & 4 \\
\hline Service & 17 & 20 & 25 & 26 & Service & 13 & 15 & 19 & 21 \\
\hline Public Administration & 5 & 6 & 5 & 5 & Public Administration & 4 & 4 & 3 & 3 \\
\hline Other & 7 & 11 & 14 & 14 & Other & 2 & 4 & 6 & 7 \\
\hline \multicolumn{10}{|l|}{ Washington } \\
\hline Construction & 8 & 8 & 11 & 11 & & & & & \\
\hline Manufacturing & 7 & 6 & 7 & 6 & & & & & \\
\hline Transportation & 9 & 9 & 9 & 10 & & & & & \\
\hline Sale & 13 & 12 & 14 & 13 & & & & & \\
\hline Finance & 4 & 5 & 6 & 5 & & & & & \\
\hline Service & 21 & 26 & 29 & 34 & & & & & \\
\hline Public Administration & 26 & 24 & 16 & 13 & & & & & \\
\hline Other & 12 & 9 & 8 & 8 & & & & & \\
\hline
\end{tabular}




\begin{tabular}{|c|c|c|c|c|c|c|c|c|c|}
\hline Year & 1970 & 1980 & 1990 & 2000 & Year & 1970 & 1980 & 1990 & 2000 \\
\hline $\begin{array}{l}\text { Western } \\
\text { Los Angeles }\end{array}$ & & & & & $\begin{array}{l}\text { Eastern } \\
\text { New York }\end{array}$ & & & & \\
\hline Construction & 7 & 7 & 9 & 9 & Construction & 6 & 5 & 7 & 8 \\
\hline Manufacturing & 33 & 29 & 23 & 17 & Manufacturing & 20 & 17 & 11 & 8 \\
\hline Transportation & 10 & 9 & 8 & 9 & Transportation & 16 & 13 & 12 & 12 \\
\hline Sale & 17 & 17 & 18 & 19 & Sale & 19 & 17 & 17 & 16 \\
\hline Finance & 4 & 5 & 6 & 5 & Finance & 8 & 9 & 11 & 10 \\
\hline Service & 20 & 23 & 25 & 30 & Service & 22 & 26 & 29 & 31 \\
\hline Public Administration & 4 & 4 & 3 & 3 & Public Administration & 5 & 6 & 5 & 5 \\
\hline Other & 4 & 6 & 7 & 9 & Other & 4 & 7 & 9 & 11 \\
\hline San Francisco & & & & & Philadelphia & & & & \\
\hline Construction & 9 & 8 & 8 & 8 & Construction & 8 & 8 & 10 & 10 \\
\hline Manufacturing & 20 & 17 & 11 & 10 & Manufacturing & 36 & 28 & 21 & 16 \\
\hline Transportation & 14 & 12 & 11 & 9 & Transportation & 10 & 10 & 9 & 10 \\
\hline Sale & 18 & 18 & 19 & 18 & Sale & 16 & 16 & 18 & 17 \\
\hline Finance & 6 & 7 & 8 & 8 & Finance & 4 & 5 & 6 & 6 \\
\hline Service & 21 & 25 & 30 & 38 & Service & 15 & 20 & 23 & 28 \\
\hline Public Administration & 7 & 6 & 4 & 3 & Public Administration & 6 & 6 & 5 & 5 \\
\hline Other & 5 & 6 & 7 & 6 & Other & 5 & 6 & 7 & 8 \\
\hline & & & & & Baltimore & & & & \\
\hline & & & & & Construction & 9 & 10 & 12 & 11 \\
\hline & & & & & Manufacturing & 31 & 22 & 16 & 12 \\
\hline & & & & & Transportation & 11 & 11 & 10 & 10 \\
\hline & & & & & Sale & 14 & 14 & 16 & 16 \\
\hline & & & & & Finance & 4 & 4 & 5 & 6 \\
\hline & & & & & Service & 15 & 18 & 22 & 28 \\
\hline & & & & & Public Administration & 9 & 13 & 11 & 9 \\
\hline & & & & & Other & 7 & 8 & 8 & 8 \\
\hline
\end{tabular}


Table 9: Employment Distribution by Industry, Black Men, \%

\begin{tabular}{|c|c|c|c|c|c|c|c|c|c|}
\hline Year & 1970 & 1980 & 1990 & 2000 & Year & 1970 & 1980 & 1990 & 2000 \\
\hline Southern & & & & & Midwestern & & & & \\
\hline Houston & & & & & St. Louis & & & & \\
\hline Construction & 14 & 12 & 8 & 7 & Construction & 7 & 6 & 5 & 6 \\
\hline Manufacturing & 24 & 25 & 16 & 12 & Manufacturing & 36 & 34 & 23 & 18 \\
\hline Transportation & 14 & 16 & 17 & 17 & Transportation & 13 & 14 & 13 & 16 \\
\hline Sale & 22 & 17 & 18 & 17 & Sale & 13 & 10 & 14 & 13 \\
\hline Finance & 3 & 2 & 3 & 3 & Finance & 1 & 2 & 3 & 3 \\
\hline Service & 17 & 15 & 22 & 25 & Service & 17 & 17 & 23 & 25 \\
\hline Public Administration & 1 & 4 & 4 & 6 & Public Administration & 8 & 7 & 6 & 5 \\
\hline Other & 6 & 8 & 12 & 13 & Other & 6 & 10 & 14 & 15 \\
\hline Memphis & & & & & Cleveland & & & & \\
\hline Construction & 11 & 8 & 9 & 7 & Construction & 6 & 4 & 5 & 6 \\
\hline Manufacturing & 28 & 26 & 16 & 15 & Manufacturing & 47 & 40 & 22 & 21 \\
\hline Transportation & 13 & 17 & 17 & 20 & Transportation & 15 & 13 & 13 & 10 \\
\hline Sale & 17 & 17 & 17 & 16 & Sale & 12 & 11 & 12 & 14 \\
\hline Finance & 1 & 2 & 2 & 2 & Finance & 3 & 2 & 4 & 4 \\
\hline Service & 15 & 15 & 19 & 20 & Service & 12 & 16 & 22 & 25 \\
\hline Public Administration & 3 & 7 & 7 & 5 & Public Administration & 3 & 5 & 5 & 5 \\
\hline Other & 11 & 9 & 12 & 15 & Other & 3 & 9 & 18 & 13 \\
\hline Atlanta & & & & & Chicago & & & & \\
\hline Construction & 13 & 10 & 9 & 8 & Construction & 6 & 5 & 5 & 4 \\
\hline Manufacturing & 25 & 20 & 15 & 13 & Manufacturing & 37 & 29 & 17 & 13 \\
\hline Transportation & 14 & 17 & 16 & 19 & Transportation & 16 & 16 & 17 & 16 \\
\hline Sale & 20 & 16 & 19 & 17 & Sale & 16 & 12 & 14 & 12 \\
\hline Finance & 2 & 4 & 5 & 5 & Finance & 2 & 4 & 5 & 5 \\
\hline Service & 15 & 18 & 23 & 25 & Service & 15 & 17 & 22 & 25 \\
\hline Public Administration & 5 & 7 & 7 & 5 & Public Administration & 4 & 5 & 5 & 5 \\
\hline Other & 6 & 8 & 6 & 8 & Other & 4 & 12 & 15 & 18 \\
\hline New Orleans & & & & & Detroit & & & & \\
\hline Construction & 14 & 13 & 9 & 11 & Construction & 6 & 4 & 5 & 5 \\
\hline Manufacturing & 21 & 15 & 10 & 12 & Manufacturing & 56 & 50 & 31 & 26 \\
\hline Transportation & 22 & 20 & 18 & 14 & Transportation & 9 & 8 & 8 & 9 \\
\hline Sale & 19 & 16 & 17 & 14 & Sale & 9 & 8 & 11 & 12 \\
\hline Finance & 3 & 2 & 3 & 3 & Finance & 2 & 2 & 3 & 3 \\
\hline Service & 15 & 17 & 21 & 22 & Service & 12 & 12 & 18 & 22 \\
\hline Public Administration & 2 & 5 & 4 & 5 & Public Administration & 3 & 6 & 6 & 4 \\
\hline Other & 5 & 12 & 18 & 20 & Other & 3 & 10 & 18 & 18 \\
\hline \multicolumn{10}{|l|}{ Washington } \\
\hline Construction & 11 & 9 & 10 & 8 & & & & & \\
\hline Manufacturing & 7 & 6 & 5 & 5 & & & & & \\
\hline Transportation & 15 & 15 & 15 & 16 & & & & & \\
\hline Sale & 17 & 12 & 14 & 13 & & & & & \\
\hline Finance & 3 & 4 & 5 & 5 & & & & & \\
\hline Service & 22 & 25 & 28 & 32 & & & & & \\
\hline Public Administration & 22 & 23 & 17 & 13 & & & & & \\
\hline Other & 4 & 6 & 6 & 8 & & & & & \\
\hline
\end{tabular}




\begin{tabular}{|c|c|c|c|c|c|c|c|c|c|}
\hline Year & 1970 & 1980 & 1990 & 2000 & Year & 1970 & 1980 & 1990 & 2000 \\
\hline $\begin{array}{l}\text { Western } \\
\text { Los Angeles }\end{array}$ & & & & & $\begin{array}{l}\text { Eastern } \\
\text { New York }\end{array}$ & & & & \\
\hline Construction & 7 & 5 & 6 & 5 & Construction & 5 & 5 & 7 & 7 \\
\hline Manufacturing & 28 & 25 & 16 & 9 & Manufacturing & 19 & 16 & 10 & 5 \\
\hline Transportation & 13 & 14 & 15 & 15 & Transportation & 21 & 17 & 17 & 16 \\
\hline Sale & 14 & 13 & 13 & 12 & Sale & 17 & 12 & 12 & 11 \\
\hline Finance & 3 & 4 & 6 & 5 & Finance & 7 & 7 & 8 & 7 \\
\hline Service & 24 & 24 & 26 & 33 & Service & 22 & 26 & 28 & 32 \\
\hline Public Administration & 6 & 6 & 6 & 5 & Public Administration & 4 & 6 & 6 & 6 \\
\hline Other & 4 & 9 & 13 & 16 & Other & 6 & 11 & 12 & 16 \\
\hline San Francisco & & & & & Philadelphia & & & & \\
\hline Construction & 12 & 7 & 6 & 5 & Construction & 8 & 7 & 8 & 6 \\
\hline Manufacturing & 18 & 16 & 8 & 5 & Manufacturing & 32 & 23 & 16 & 11 \\
\hline Transportation & 21 & 18 & 16 & 14 & Transportation & 15 & 13 & 13 & 12 \\
\hline Sale & 10 & 12 & 12 & 15 & Sale & 12 & 12 & 15 & 15 \\
\hline Finance & 2 & 5 & 5 & 5 & Finance & 2 & 3 & 4 & 5 \\
\hline Service & 20 & 23 & 32 & 37 & Service & 18 & 20 & 25 & 30 \\
\hline Public Administration & 14 & 9 & 5 & 5 & Public Administration & 8 & 9 & 8 & 7 \\
\hline \multirow[t]{10}{*}{ Other } & 4 & 11 & 16 & 14 & Other & 5 & 12 & 13 & 14 \\
\hline & & & & & Baltimore & & & & \\
\hline & & & & & Construction & 9 & 9 & 9 & 7 \\
\hline & & & & & Manufacturing & 32 & 23 & 15 & 11 \\
\hline & & & & & Transportation & 17 & 14 & 14 & 13 \\
\hline & & & & & Sale & 12 & 12 & 14 & 15 \\
\hline & & & & & Finance & 2 & 4 & 4 & 4 \\
\hline & & & & & Service & 16 & 18 & 22 & 27 \\
\hline & & & & & Public Administration & 7 & 11 & 11 & 10 \\
\hline & & & & & Other & 5 & 10 & 11 & 13 \\
\hline
\end{tabular}




\section{Table 10: Population Changes by MSA, \%}

\begin{tabular}{l|ccc}
\hline Year & $\mathbf{1 9 7 0 - 1 9 8 0}$ & $\mathbf{1 9 8 0} \mathbf{- 1 9 9 0}$ & $\mathbf{1 9 9 0} \mathbf{- 2 0 0 0}$ \\
\hline Southern & 45 & 21 & 24 \\
Houston & 10 & 7 & 12 \\
Memphis & 27 & 33 & 35 \\
Atlanta & 14 & -1 & 4 \\
New Orleans & 9 & 21 & 15 \\
Washington & & & \\
\hline Eastern & -9 & 3 & 8 \\
New York & -2 & 3 & 3 \\
Philadelphia & 5 & 8 & 7 \\
Baltimore & & & 2 \\
\hline Midwestern & -2 & 3 & 11 \\
St. Louis & -6 & -3 & 4 \\
Cleveland & 2 & 2 & 6 \\
Chicago & -2 & -3 & 8 \\
Detroit & & & 13 \\
\hline Western & 6 & 19 & 4 \\
Los Angeles & 0 & 10 & \\
San Francisco & 11 & & \\
\hline United States & & & \\
\hline
\end{tabular}

Note: Data are Population and Household Data, U.S. Metropolitan Statistical Areas, MSA (1999 definition), 1970 - Present. Metropolitan Population Database, Real Estate Center, Texas A\&M University. http://recenter.tamu.edu/data/popm/ 
Table 11: Black Population Changes by MSA, \%

\begin{tabular}{l|ccc}
\hline Year & $\mathbf{1 9 7 0} \mathbf{- 1 9 8 0}$ & $\mathbf{1 9 8 0} \mathbf{- 1 9 9 0}$ & $\mathbf{1 9 9 0} \mathbf{- 2 0 0 0}$ \\
\hline Southern & & & \\
Houston & 37 & 18 & 22 \\
Memphis & 16 & 9 & 14 \\
Atlanta & 41 & 39 & 33 \\
New Orleans & 19 & 5 & 2 \\
Washington & 15 & 20 & 11 \\
\hline Eastern & & & \\
New York & 13 & 22 & 3 \\
Philadelphia & 5 & 6 & 4 \\
Baltimore & 13 & 10 & 73 \\
\hline Midwestern & & & 7 \\
St. Louis & 7 & 4 & 7 \\
Cleveland & 5 & 3 & 7 \\
Chicago & 17 & 0 & 1 \\
Detroit & 16 & 6 & 2 \\
\hline Western & & 9 & 16 \\
Los Angeles & 24 & -4 & 13 \\
San Francisco & 1 & & \\
\hline United States & 17 & & \\
\hline
\end{tabular}

Note: Data are from Population Estimates Archives, U.S. Census Bureau. 
Table 12: Population of Black Men Changes by MSA, \%

\begin{tabular}{l|ccc}
\hline Year & $\mathbf{1 9 7 0} \mathbf{- 1 9 8 0}$ & $\mathbf{1 9 8 0} \mathbf{- 1 9 9 0}$ & $\mathbf{1 9 9 0} \mathbf{- 2 0 0 0}$ \\
\hline Southern & & & \\
Houston & 37 & 18 & 21 \\
Memphis & 15 & 8 & 14 \\
Atlanta & 41 & 41 & 33 \\
New Orleans & 18 & 3 & 2 \\
Washington & 13 & 19 & 11 \\
\hline Eastern & & & \\
New York & 11 & 23 & 4 \\
Philadelphia & 4 & 6 & 4 \\
Baltimore & 11 & 10 & 7 \\
\hline Midwestern & & 3 & 9 \\
St. Louis & 6 & 2 & 7 \\
Cleveland & 3 & 0 & 7 \\
Chicago & 15 & 4 & 0 \\
Detroit & 14 & 9 & 2 \\
\hline Western & & -2 & \\
Los Angeles & 24 & 2 & \\
San Francisco & 2 & & \\
\hline
\end{tabular}

Note: Data are from Population Estimates Archives, U.S. Census Bureau. 
Table 13: Population of White Men Changes by MSA, \%

\begin{tabular}{l|ccc}
\hline Year & $\mathbf{1 9 7 0 - 1 9 8 0}$ & $\mathbf{1 9 8 0} \mathbf{- 1 9 9 0}$ & $\mathbf{1 9 9 0} \mathbf{- 2 0 0 0}$ \\
\hline Southern & 48 & -15 & 9 \\
Houston & 4 & 5 & 5 \\
Memphis & 22 & 26 & 24 \\
Atlanta & 11 & -12 & -1 \\
New Orleans & -1 & 11 & 6 \\
Washington & & & \\
\hline Eastern & -17 & -31 & -9 \\
New York & -5 & -3 & -3 \\
Philadelphia & 1 & 5 & 0 \\
Baltimore & -4 & 2 & 2 \\
\hline Midwestern & -8 & -8 & -2 \\
St. Louis & -3 & -14 & 2 \\
Cleveland & -8 & -8 & 3 \\
Chicago & & & \\
Detroit & 1 & -40 & -14 \\
\hline Western & -6 & -18 & -9 \\
Los Angeles & & & \\
San Francisco & & & 2 \\
\hline
\end{tabular}

Note: Data are from Population Estimates Archives, U.S. Census Bureau. 


\section{Table 14: Black Non-Migrant Men Ratios by MSA, \%}

\begin{tabular}{l|cccc}
\hline Year & $\mathbf{1 9 7 0}$ & $\mathbf{1 9 8 0}$ & $\mathbf{1 9 9 0}$ & $\mathbf{2 0 0 0}$ \\
\hline Southern & & & & \\
Live in Houston, born in TX & 74 & 65 & 61 & 61 \\
Live in Memphis, born in TN \& MS & 91 & 91 & 88 & 84 \\
Live in Atlanta, born in GA & 86 & 73 & 55 & 43 \\
Live in New Orleans, born in LA & 82 & 81 & 84 & 86 \\
Live in DC, born in MD, VA \& DC & 56 & 50 & 52 & 52 \\
\hline Eastern & & & & 40 \\
Live in New York, born in NY & 38 & 30 & 69 & 73 \\
Live in Philadelphia, born in PA \& NJ & 54 & 59 & 65 & 66 \\
Live in Baltimore, born in MD & 54 & 58 & & 64 \\
\hline Midwestern & & & 58 & 72 \\
Live in St. Louis, born in MO & 37 & 44 & 57 & 67 \\
Live in Cleveland, born in OH & 34 & 41 & 56 & 69 \\
Live in Chicago, born in IL & 36 & 38 & 58 & 47 \\
Live in Detroit, born in MI & 28 & 39 & & 45 \\
\hline Western & & & 34 & 37 \\
Live in Los Angeles, born in CA & 13 & 21 & & \\
Live in San Francisco, born in CA & 15 & 25 & & \\
\hline
\end{tabular}

Note: Authors' calculations. See Appendix 1 for details. 


\section{Table 15: Marital Status of Black Men by MSA, \%}

\begin{tabular}{|c|c|c|c|c|c|c|c|c|c|}
\hline Year & 1970 & 1980 & 1990 & 2000 & Year & 1970 & 1980 & 1990 & 2000 \\
\hline Southern & & & & & Midwestern & & & & \\
\hline Houston & & & & & St. Louis & & & & \\
\hline Married & 83 & 67 & 54 & 54 & Married & 75 & 59 & 47 & 45 \\
\hline Div./Sep./Widowed & 11 & 17 & 21 & 18 & Div./Sep./Widowed & 15 & 23 & 20 & 21 \\
\hline Never Married & 6 & 16 & 26 & 28 & Never Married & 10 & 18 & 33 & 34 \\
\hline Memphis & & & & & Cleveland & & & & \\
\hline Married & 75 & 58 & 49 & 48 & Married & 78 & 60 & 47 & 43 \\
\hline Div./Sep./Widowed & 19 & 22 & 21 & 20 & Div./Sep./Widowed & 15 & 21 & 25 & 22 \\
\hline Never Married & 6 & 20 & 30 & 32 & Never Married & 7 & 19 & 28 & 35 \\
\hline Atlanta & & & & & Chicago & & & & \\
\hline Married & 74 & 61 & 53 & 53 & Married & 76 & 57 & 44 & 44 \\
\hline Div./Sep./Widowed & 16 & 19 & 18 & 16 & Div./Sep./Widowed & 14 & 21 & 21 & 19 \\
\hline Never Married & 10 & 20 & 29 & 31 & Never Married & 10 & 21 & 36 & 38 \\
\hline New Orleans & & & & & Detroit & & & & \\
\hline Married & 75 & 61 & 50 & 50 & Married & 73 & 55 & 43 & 42 \\
\hline Div./Sep./Widowed & 13 & 20 & 20 & 20 & Div./Sep./Widowed & 16 & 24 & 23 & 18 \\
\hline Never Married & 12 & 18 & 30 & 30 & Never Married & 11 & 21 & 34 & 39 \\
\hline Washington & & & & & Eastern & & & & \\
\hline Married & 72 & 56 & 49 & 51 & New York & & & & \\
\hline Div./Sep./Widowed & 14 & 22 & 17 & 16 & Married & 74 & 57 & 49 & 46 \\
\hline Never Married & 14 & 23 & 34 & 33 & Div./Sep./Widowed & 12 & 19 & 17 & 15 \\
\hline Western & & & & & Never Married & 13 & 24 & 35 & 39 \\
\hline Los Angeles & & & & & Philadelphia & & & & \\
\hline Married & 72 & 55 & 46 & 44 & Married & 71 & 54 & 45 & 44 \\
\hline Div./Sep./Widowed & 17 & 23 & 21 & 18 & Div./Sep./Widowed & 15 & 23 & 20 & 16 \\
\hline Never Married & 11 & 22 & 34 & 38 & Never Married & 14 & 23 & 35 & 39 \\
\hline San Francisco & & & & & Baltimore & & & & \\
\hline Married & 73 & 51 & 39 & 31 & Married & 71 & 52 & 44 & 46 \\
\hline Div./Sep./Widowed & 15 & 23 & 21 & 20 & Div./Sep./Widowed & 15 & 24 & 20 & 18 \\
\hline Never Married & 12 & 26 & 40 & 49 & Never Married & 14 & 24 & 36 & 36 \\
\hline
\end{tabular}

Note: Authors' calculations. See Appendix 1 for details. 


\section{Table 16: Marital Status of White Men by MSA, \%}

\begin{tabular}{|c|c|c|c|c|c|c|c|c|c|}
\hline Year & 1970 & 1980 & 1990 & 2000 & \begin{tabular}{|l|} 
Year \\
\end{tabular} & 1970 & 1980 & 1990 & 2000 \\
\hline Southern & & & & & Midwestern & & & & \\
\hline Houston & & & & & St. Louis & & & & \\
\hline Married & 88 & 76 & 70 & 69 & Married & 88 & 81 & 72 & 69 \\
\hline Div./Sep./Widowed & 6 & 12 & 13 & 14 & Div./Sep./Widowed & 5 & 9 & 11 & 13 \\
\hline Never Married & 6 & 12 & 17 & 17 & Never Married & 7 & 11 & 17 & 18 \\
\hline Memphis & & & & & Cleveland & & & & \\
\hline Married & 89 & 79 & 72 & 69 & Married & 86 & 77 & 69 & 66 \\
\hline Div./Sep./Widowed & 4 & 11 & 11 & 15 & Div./Sep./Widowed & 5 & 8 & 11 & 13 \\
\hline Never Married & 7 & 11 & 16 & 16 & Never Married & 9 & 14 & 20 & 21 \\
\hline Atlanta & & & & & Chicago & & & & \\
\hline Married & 88 & 77 & 71 & 69 & Married & 84 & 75 & 66 & 67 \\
\hline Div./Sep./Widowed & 5 & 11 & 11 & 12 & Div./Sep./Widowed & 5 & 9 & 10 & 10 \\
\hline Never Married & 7 & 12 & 18 & 19 & Never Married & 11 & 16 & 24 & 23 \\
\hline New Orleans & & & & & Detroit & & & & \\
\hline Married & 85 & 74 & 66 & 63 & Married & 87 & 78 & 71 & 67 \\
\hline Div./Sep./Widowed & 6 & 11 & 13 & 14 & Div./Sep./Widowed & 5 & 10 & 11 & 12 \\
\hline Never Married & 10 & 15 & 21 & 22 & Never Married & 9 & 13 & 18 & 21 \\
\hline Washington & & & & & Eastern & & & & \\
\hline Married & 85 & 71 & 65 & 66 & New York & & & & \\
\hline Div./Sep./Widowed & 5 & 11 & 10 & 11 & Married & 78 & 67 & 59 & 58 \\
\hline Never Married & 10 & 19 & 24 & 23 & Div./Sep./Widowed & 5 & 9 & 9 & 9 \\
\hline Western & & & & & Never Married & 17 & 25 & 33 & 34 \\
\hline Los Angeles & & & & & Philadelphia & & & & \\
\hline Married & 79 & 63 & 56 & 54 & Married & 85 & 76 & 70 & 68 \\
\hline Div./Sep./Widowed & 9 & 15 & 14 & 13 & Div./Sep./Widowed & 5 & 9 & 9 & 10 \\
\hline Never Married & 12 & 22 & 30 & 33 & Never Married & 10 & 15 & 21 & 22 \\
\hline San Francisco & & & & & Baltimore & & & & \\
\hline Married & 79 & 62 & 50 & 47 & Married & 86 & 76 & 70 & 67 \\
\hline Div./Sep./Widowed & 8 & 14 & 13 & 11 & Div./Sep./Widowed & 6 & 11 & 12 & 13 \\
\hline Never Married & 14 & 24 & 37 & 42 & Never Married & 8 & 14 & 19 & 20 \\
\hline
\end{tabular}

Note: Authors' calculations. See Appendix 1 for details. 
Table 17: Well-Being of Black Children Compared to White Children: Place in Family Income Distribution of White Children (Percentile)

\begin{tabular}{|c|c|c|c|c|c|c|c|c|c|}
\hline Year & 1970 & 1980 & 1990 & 2000 & Year & 1970 & 1980 & 1990 & 2000 \\
\hline $\begin{array}{l}\text { Southern } \\
\text { Houston }\end{array}$ & & & & & $\begin{array}{l}\text { Midwestern } \\
\text { St. Louis }\end{array}$ & & & & \\
\hline $75^{\text {th }}$ percentile & 27 & 38 & 39 & 38 & $75^{\text {th }}$ percentile & 37 & 37 & 39 & 33 \\
\hline median & 12 & 14 & 15 & 16 & median & 12 & 12 & 13 & 12 \\
\hline $25^{\text {th }}$ percentile & 4 & 4 & 4 & 6 & $25^{\text {th }}$ percentile & 4 & 4 & 4 & 4 \\
\hline ratio of medians & 0.5 & 0.5 & 0.5 & 0.4 & ratio of medians & 0.5 & 0.4 & 0.4 & 0.4 \\
\hline Memphis & & & & & Cleveland & & & & \\
\hline $75^{\text {th }}$ percentile & 20 & 34 & 32 & 33 & $75^{\text {th }}$ percentile & 35 & 43 & 44 & 39 \\
\hline median & 8 & 14 & 10 & 12 & median & 10 & 12 & 15 & 14 \\
\hline $25^{\text {th }}$ percentile & 4 & 5 & 3 & 3 & $25^{\text {th }}$ percentile & 4 & 4 & 4 & 5 \\
\hline ratio of medians & 0.4 & 0.4 & 0.4 & 0.4 & ratio of medians & 0.5 & 0.5 & 0.5 & 0.4 \\
\hline Atlanta & & & & & Chicago & & & & \\
\hline $75^{\text {th }}$ percentile & 27 & 32 & 39 & 40 & $75^{\text {th }}$ percentile & 33 & 37 & 37 & 34 \\
\hline median & 12 & 15 & 13 & 17 & median & 11 & 11 & 11 & 11 \\
\hline $25^{\text {th }}$ percentile & 6 & 3 & 10 & 7 & $25^{\text {th }}$ percentile & 4 & 4 & 3 & 3 \\
\hline ratio of medians & 0.5 & 0.5 & 0.5 & 0.5 & ratio of medians & 0.6 & 0.4 & 0.4 & 0.4 \\
\hline New Orleans & & & & & Detroit & & & & \\
\hline $75^{\text {th }}$ percentile & 26 & 35 & 32 & 35 & $75^{\text {th }}$ percentile & 45 & 45 & 41 & 42 \\
\hline median & 10 & 13 & 9 & 14 & median & 14 & 18 & 14 & 16 \\
\hline $25^{\text {th }}$ percentile & 4 & 4 & 3 & 4 & $25^{\text {th }}$ percentile & 4 & 7 & 5 & 6 \\
\hline ratio of medians & 0.5 & 0.4 & 0.3 & 0.4 & ratio of medians & 0.6 & 0.6 & 0.4 & 0.5 \\
\hline Washington & & & & & Eastern & & & & \\
\hline $75^{\text {th }}$ percentile & 33 & 44 & 47 & 40 & New York & & & & \\
\hline median & 13 & 17 & 17 & 17 & $75^{\text {th }}$ percentile & 40 & 40 & 46 & 43 \\
\hline $25^{\text {th }}$ percentile & 6 & 6 & 5 & 4 & median & 15 & 16 & 21 & 23 \\
\hline ratio of medians & 0.5 & 0.6 & 0.6 & 0.5 & $25^{\text {th }}$ percentile & 6 & 6 & 7 & 7 \\
\hline $\begin{array}{l}\text { Western } \\
\text { Los Angeles }\end{array}$ & & & & & $\begin{array}{l}\text { ratio of medians } \\
\text { Philadelphia }\end{array}$ & 0.5 & 0.5 & 0.5 & 0.5 \\
\hline $75^{\text {th }}$ percentile & 36 & 44 & 51 & 39 & $75^{\text {th }}$ percentile & 44 & 41 & 46 & 40 \\
\hline median & 15 & 20 & 18 & 17 & median & 14 & 15 & 14 & 13 \\
\hline $25^{\text {th }}$ percentile & 6 & 8 & 7 & 6 & $25^{\text {th }}$ percentile & 5 & 5 & 5 & 4 \\
\hline ratio of medians & 0.5 & 0.5 & 0.5 & 0.4 & ratio of medians & 0.6 & 0.5 & 0.5 & 0.5 \\
\hline San Francisco & & & & & Baltimore & & & & \\
\hline $75^{\text {th }}$ percentile & 46 & 41 & 37 & 36 & $75^{\text {th }}$ percentile & 46 & 41 & 43 & 41 \\
\hline median & 16 & 17 & 17 & 11 & median & 16 & 15 & 15 & 16 \\
\hline $25^{\text {th }}$ percentile & 7 & 6 & 4 & 4 & $25^{\text {th }}$ percentile & 6 & 3 & 6 & 4 \\
\hline ratio of medians & 0.6 & 0.5 & 0.5 & 0.3 & ratio of medians & 0.6 & 0.5 & 0.5 & 0.5 \\
\hline
\end{tabular}


Figure 1. Average Weeks of Work per Year by Black Males: 1970 - 2000

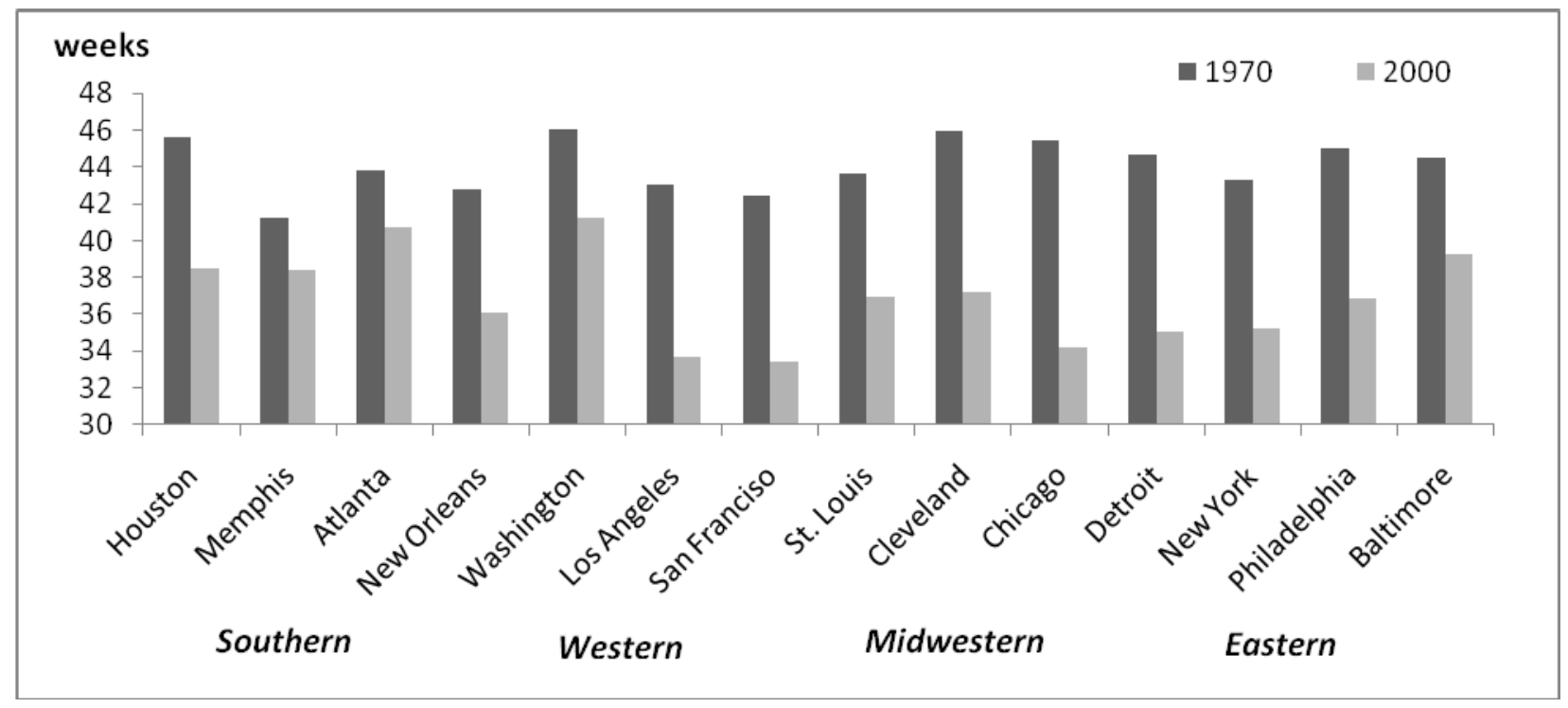

Figure 2. Average Hours of Work per Week by Black Males: 1970 - 2000

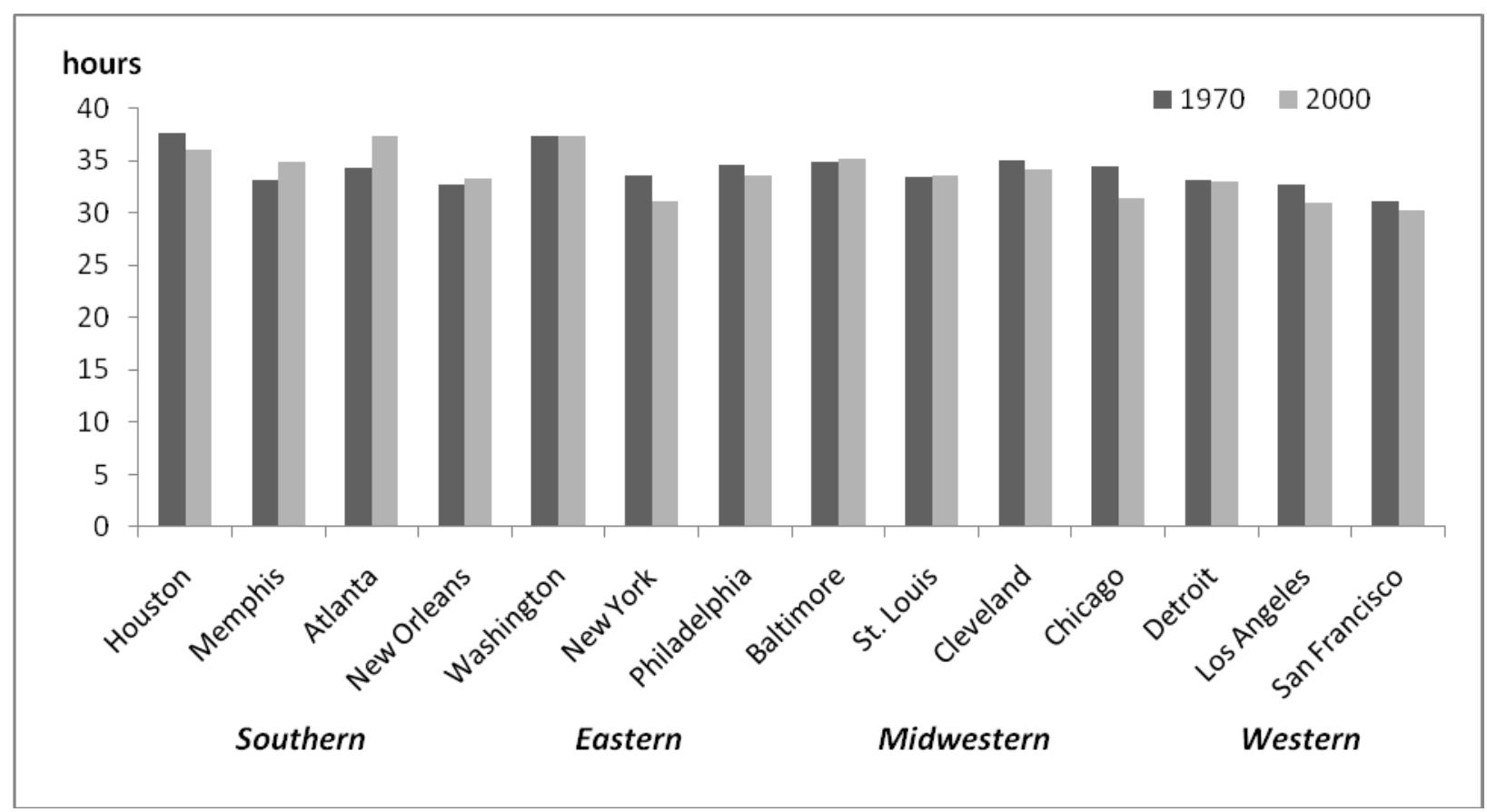


Figure 3. Educational Attainment of Black and White Men: 1970-2000
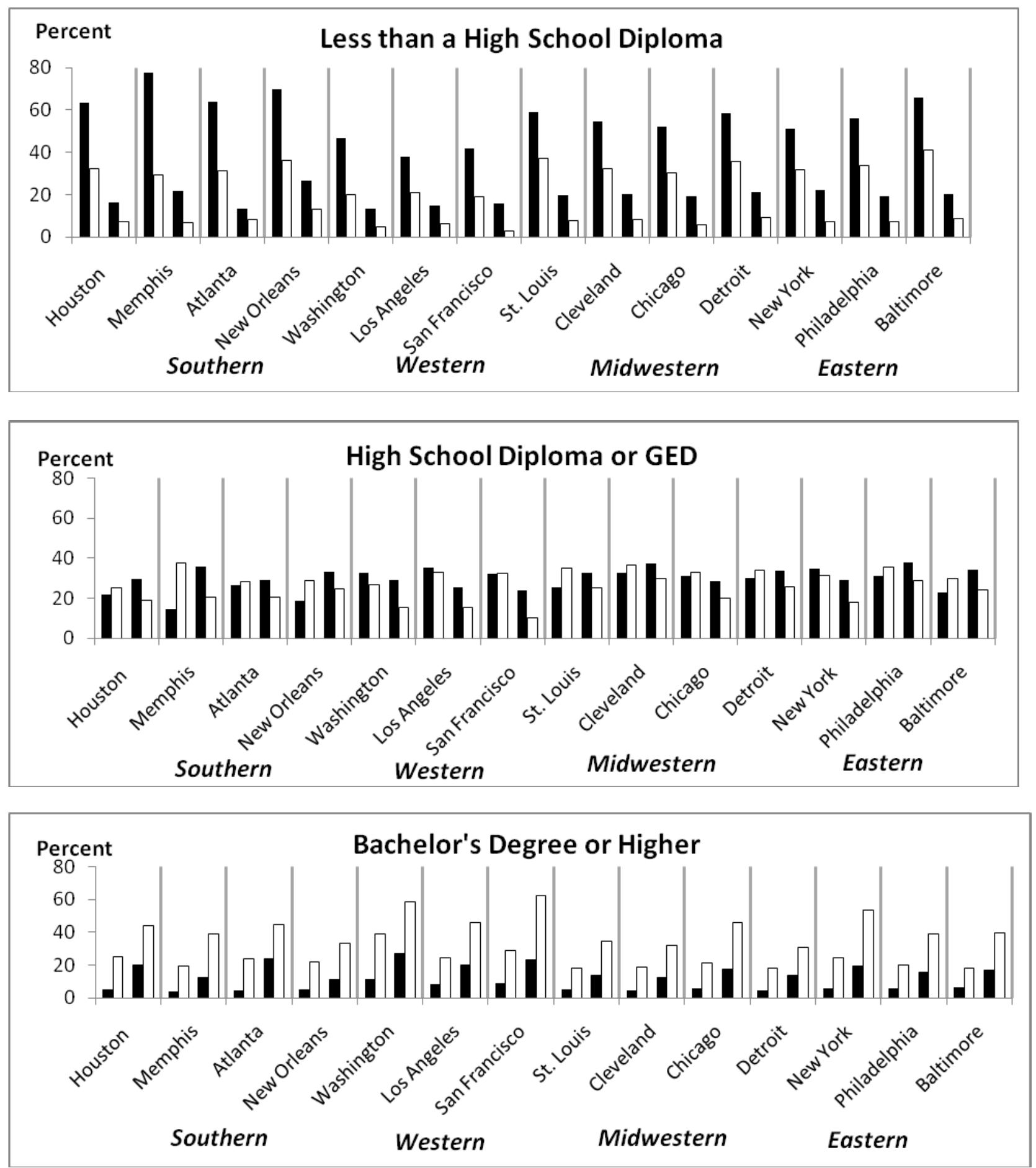

Note: For each city, the first two bars represent an educational attainment of black men (black bars) and white men (white bars) in 1970. The second two bars represent an educational attainment of black and white men, respectively, in 2000. 


\section{Figure 4. Marital Status of Black Men: 1970-2000}
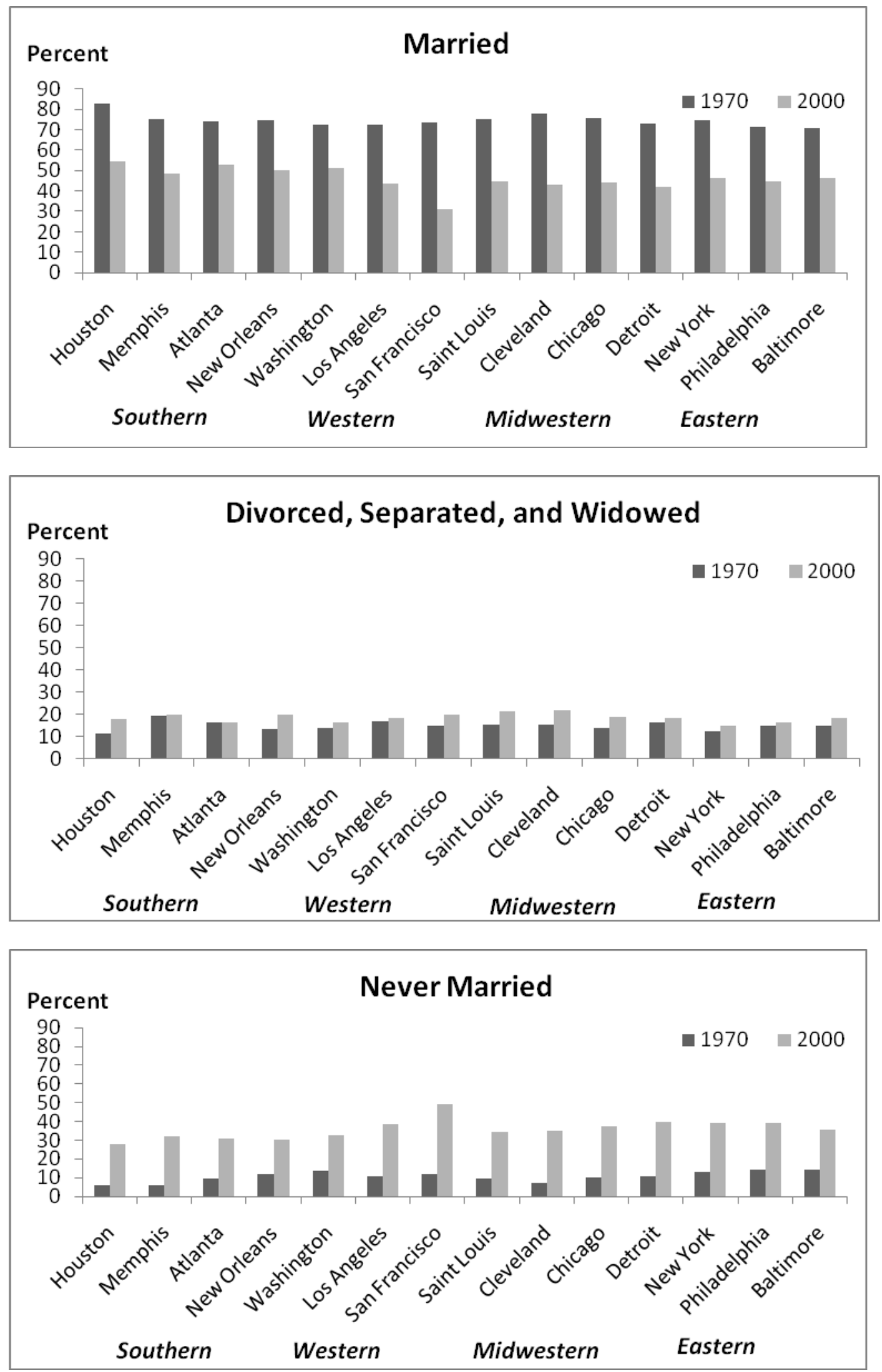